\title{
Economic Growth and Socioeconomic Sustainability in BRICS Countries: A Vector Error Correction Modeling Approach
}

\author{
Olawumi D. Awolusi \\ Department of Accounting and Finance, College of Economics and Management, Kampala International \\ University, Kampala, Uganda \\ awolusi.olawumi@kiu.ac.ug, 217080603@stu.ukzn.ac.za
}

\begin{abstract}
A major problem to the BRICS goal of achieving sustainable economic growth for members is the increasing level of socioeconomic inequality in the bloc. Consequently, the purpose of this study is to understand the influence of economic growth on socio-economic sustainability in the BRICS countries, using a yearly dataset from 1990 to 2019. A multivariate co-integration technique by Johansen and Juselius and Granger causality test were used to establish the relationships. Findings confirmed co-integration and shortrun causal relationships. The most interesting results were the negative influence of economic growth on socio-economic inequality, tacit support for the resource curse hypothesis. The paper concluded that a common policy option was not possible and that for the block to pursue its economic prosperity goals without compromising individual countries' needs for socioeconomic sustainability, varied policy options were inevitable. The policy implications and recommendations are straightforward: the radical legal basis for the transition from natural resource export, as well as, sweeping regulation for the sustainable usage of natural resources protection, strict penalties on violations of environment-related laws and policies to enhance, general country-wide support. In addition, there may be an urgent need to define the active role of NGOs and other independent institutions in promoting socioeconomic equality (sustainability) practices and concepts at both local and national levels, enhanced social programs; market development, Integration of existing policies and creation of societal culture. Consequently, to the best of the researcher's knowledge, no study has investigated comprehensibly (along with multiple determinants) the sustainability of growth policy options within BRICS with an aim to proposing socioeconomic sustainability and growth policy options.
\end{abstract}

Keywords: Socioeconomic inequality, economic growth, Cointegration, Vector Error Correction Modeling, BRICS.

\section{Introduction}

Sustainable development is anchored on three dimensions; however, for this development to bring about balanced wellbeing, this paper focuses on one dimension, the socio-economic dimension of sustainability in BRICS countries (Awolusi \& Mbonigaba, 2020; Zha et al., 2019; Younsi \& Bechtini, 2018). Socio-economic inequality is therefore our proxy for socio-economic sustainability. Over the past few decades, the interaction of economic growth and socio-economic sustainability has been a subject of interest among policymakers (Hussin, Muhammad, Abu \& Awang, 2012; Jamel \& Maktouf, 2017; Agrawal, 2015). Many studies often emphasize two intertwined levels in the relationship between economic growth and socio-economic inequality in that "economic growth may negatively alter the distribution of capital and resources in an economy", which many referred to as "resource curse" (Awan, 2013; Menon, 2017; Agarwal \& Khan, 2011; Gur, 2015). BRICS (Brazil, Russia, India, China and South Africa) as a bloc is also not immune to the above problem.

Specifically, after nearly two decades of its existence, sustainability of economic growth in the BRICS (Brazil, Russia, India, China and South Africa) countries has been documented. As a major problem given the diverse nature of socio-economic characteristics in the group, especially, as some members of the group change status from emerging economies to developed economies (Awolusi \& Mbonigaba, 2020; Younsi \& Bechtini, 2018; Javeria et al., 2017; Jamel \& Maktouf, 2017; Agrawal, 2015). Therefore, understanding the knowledge of how economic growth would affect the socio-economic sustainability of individual countries is important in solving this problem (Menon, 2017; Gur, 2015). Consequently, the main objective of this study is to assess the influence of economic growth on socioeconomic inequalities in the BRICS countries, based on a yearly dataset from 1990 to 2017. This paper seeks to provide this evidence to provide policy options in case economic growth leads to different effects of socio-economic inequalities in component countries. 
Specifically, to compare evidence on the influence of economic growth on socio-economic sustainability measured in terms of socio-economic inequality in individual BRICS countries the study seeks to understand. The short and long-run connection between economic growth and socio-economic inequalities (proxy for socio-economic sustainability) in the BRICS countries, via multivariate co-integration analysis. This involved testing for Granger-causality within a Vector Error-Correction Modeling (VECM) framework (Younsi \& Bechtini, 2018; Javeria et al., 2017; Hussin et al., 2012). Although the ARDL model was introduced by Pesaran to incorporate I(0) and I(1) variables in the same estimation since OLS can only regress stationary variables that are I(0), the VECM (Johanson Approach) is preferred in this paper since all our variables may not be stationary at I(1) (Menon, 2017; Aregbesola, 2014).

\section{Review of Related Literature}

Conceptual and Theoretical Frameworks: "Sustainability" in this study means putting scientific, technical, economic, social and ecological resources to ensure the maintenance of equilibrium state for some giving space and time (Younsi \& Bechtini, 2018; Odunlami \& Awolusi, 2015). Hence, "socio-economic sustainability" is defined as maintaining a stable level of social contacts, training, social security, education, income, communication and participation (known as core microelements/ level of socio-economic sustainability), as well as, steady circulation of assets and income (known as the core macro perspective of socio-economic sustainability) for some time and in space (Younsi \& Bechtini, 2018; Ogasawara, 2018; Spangenberg, 2004). Socio-economic sustainability is therefore posited as the maintenance of social capital (Odunlami \& Awolusi, 2015; Spangenberg, 2004). "Socio-economic sustainability" and "economic growth" analysis usually involve solving complex diagnostic problems, owing to its focus on long-run processes, a mix of varied sustainability theories and models can help in addressing these complexities over time (Menon, 2017). Consequently, the theoretical framework for this study is built largely on the classical theory of economic growth and the neoclassical growth theory (Pistorius, 2004; Wilhelms, 1998).

Many studies have severally put forward the positive linkages between socioeconomic sustainability and economic growth. As well as, the notion of "limits" on socioeconomic-sustainability activities that would spur sustainable development (Zha et al., 2019; Hofkes, 2017; Menon, 2017). Specifically, Younsi \& Bechtini (2018) study posited that issues arising from increasing socioeconomic inequalities and uneven wealth distribution throughout the world have often questioned the objective of continued growth in the past three decades (Hofkes, 2017; Menon, 2017). Although socioeconomic sustainability was seen as an offshoot of the various critiques of growth proposed by the neoclassical corpus theorists, Solow's model, as somewhat modified, is still the main neoclassical theory's response to the lingering debates on sustainability (Zha et al., 2019; Younsi \& Bechtini, 2018). Consequently, previous studies often developed neoclassical growth models with technical progress as an exogenous variable, along with labor, capital, and a non-renewable resource in the same production function (Younsi \& Bechtini, 2018). Neoclassical economists maintained that the main objective of any economic growth and socioeconomic sustainability should always consider the need to maintain steady and high economic well-being over time in the society, as well as, an extension of the same economic wellbeing to future generations (Menon, 2017; Hamilton, 2015).

Hence, Neoclassical economists defined sustainability as the "non-decline," well-being of individuals over time, probably measured by the level of individual consumption, income, and utility (Gur, 2015; Fan \& Zheng, 2013). Consequently, with high savings rates in capital stocks and production capacity (like knowledge, amenities, educations and training, skills, and natural resources) over time, socioeconomic sustainability could be achieved in the BRICS countries (Zha et al., 2019). Hence, "natural capital" was considered by the neoclassical theorists' as a particular form of capital. However, neoclassical theorists insist on "substitutability" (that increase in generated capital by societies should compensate for any decrease in "natural capital") between these different forms of capital in an attempt to ensure a steady, productive capacity and well-being over time (Younsi \& Bechtini, 2018; Menon, 2017). The neoclassical growth theory can, therefore, be used to explain the problem of diversity in the level of socioeconomic sustainability in the BRICS countries, which is probably because many BRICS countries pursue their interests that are counterproductive to the interests of other members and therefore against the common interest of the bloc (Javeria et al., 2017). Specifically, the neoclassical theory views growth as arising from strategic accretion of factors of production and the growth in total factor productivity (Pistorius, 2004). 
The neoclassical growth theory assumed that growth is automatic, cost-free and inevitable, as well as, the fact that growth is bound to continue in the future at the same rate as the past ("the trend"). Since the incoming generations are expected to be richer and better equipped to afford the cost of repairing the present environmental damages (Javeria et al., 2017; Ayres et al., 2007). The theory also conditioned the attainment of socioeconomic sustainability and economic growth on the bargaining power of the host nation. It also conditioned it on the willingness to provide socioeconomic sustainability-induced policies and infrastructures relative to the availability of labor, capital, and technology (Onuonga, 2020; Bese \& Kalayci, 2019; Fedderke \& Romm, 2005). Consequently, many studies (Zha et al., 2019; Younsi \& Bechtini, 2018) advised that any socioeconomic sustainability-induced policies should also consider other arms of sustainability, namely, institutional development and environmental protection (Javeria et al., 2017).

\section{Methodology}

This study is an attempt to compare evidence on the influence of economic growth on socio-economic, sustainability in individual BRICS countries. Hence we established the short and long-term equilibrium relationships, as well as, establishing the joint effect and the direction of Granger causality between economic growth and socio-economic sustainability (proxy by socio-economic inequalities) within individual BRICS economies.

Econometric Model: Time-series data of the five BRICS countries, from 1990 to 2017, was utilized in this study.

Derivation of Vector Error-Correction Modeling (VECM): The econometric model for this study was derived from the basic production function (El-Wassal, 2012). Consequently, to analyze the effect of economic growth on socio-economic inequalities, the basic Coub-Douglas Production Function was extended (Oladipo, 2008; El-Wassal, 2012). Therefore:

$\mathrm{Y}_{\mathrm{t}}=\beta_{0}+\lambda \varepsilon_{\mathrm{t}-1}+\beta_{1} \mathrm{X}_{\mathrm{t}}+\mu+\varepsilon_{\mathrm{t}}$ Equation 2.1

Where $Y_{t}$ is the socio-economic inequality; $X_{t}$ is the relevant explanatory socio-economic-economic growth variables; $\mu$ represents our country-specific time-invariant effects, and $\varepsilon_{t}$ is the error term. According to ElWassal (2012), by relaxing the strict exogeneity assumption, Equation 2.1 can be translated to Equation 2.2 in order to remove the country-specific effect:

$\mathrm{G}_{\mathrm{t}}-\mathrm{G}_{\mathrm{t}-1}=\eta\left(\mathrm{G}_{\mathrm{t}-1}-\mathrm{G}_{\mathrm{t}-2}\right)+\beta\left(\mathrm{X}_{\mathrm{t}}+\mathrm{X}_{\mathrm{t}-1}\right)+\left(\varepsilon_{\mathrm{t}}+\varepsilon_{\mathrm{t}-1}\right)$

Equation 2.2

Based on this method, Equation 2.2 automatically controls for the association between $\varepsilon_{t}-\varepsilon_{t-1}$ (new error term) and $\mathrm{G}_{\mathrm{t}-1}-\mathrm{G}_{\mathrm{t}-2}$ (lagged dependent variable). Therefore, using the Bundell-Blond approach (El-Wassal, 2012 ) and its basic assumptions, in addition to the introduction of some vector ( $\mathrm{X}^{1}$ ) of some controls perceived to affect socio-economic inequality, the resultant socio-economic model for this study is shown in Equation 2.3:

$\mathrm{INQ}_{t}=\left\{\operatorname{InHEALTH}_{t}, \operatorname{lnEDU}_{t}, \operatorname{lnFIN}_{t}, \operatorname{lnINST}_{t}, \operatorname{lnGDP}_{t}, \operatorname{lnTO}_{t}, \operatorname{lnCO}_{t}, \operatorname{lnEC}_{t}\right\}$ Equation 2.3

However, the VECM model provides long-term relationships, as well as, short-term dynamics of the endogenous variables, which we expect to converge to their co-integrated relations in the long run (Awolusi, 2019; Lee and Tan, 2006). Specifically, VECM shows the attainment of long-term equilibrium, as well as, the rate of change in the short term to achieve equilibrium (Akinola \& Bokana, 2017). Based on a methodology from Jamel and Maktouf (2017) and Maryam et al. (2017): Where Z represents the various dependent variables, The study posits the following:

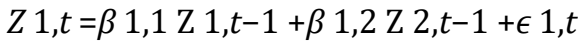
Equation 2.4

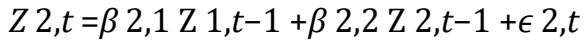
...Equation 2.5 So

$Z 1, t-\mathrm{Z} 1, t-1=(\beta 1,1-1) \mathrm{Z} 1, t-1+\beta 1,2 \mathrm{Z} 2, t-1+\epsilon 1, t$ Equation 2.5.1

$\Delta \mathrm{Z} \mathrm{1,t}=(\beta 1,1-1) \mathrm{Z} 1, t-1+\beta 1,2 \mathrm{Z} \mathrm{2,t-1}+\epsilon 1, t$ Equation 2.5.2 Given that $(\beta 1,1-1)=\phi 1 ; \beta 1,2=-\phi 1 \lambda$ we can then generate: $\Delta \mathrm{Z} 1, t=(\beta 1,1-1) \mathrm{Z} 1, t-1+\beta 1,2 \mathrm{Z} \mathrm{2,t-1}+\epsilon 1, t$ Equation 2.5.3 $\Delta \mathrm{Z} 1, t=\phi 1 \mathrm{Z} 1, t-1-\phi 1 \lambda Z 2, t-1+\epsilon 1, t$ Equation 2.5.4 
$\Delta \mathrm{Z} 1, t=\phi 1(\mathrm{Z} 1, t-1-\lambda \mathrm{Z} 2, t-1)+\epsilon 1, t$ Equation 2.5.6 Consequently, Equation 2.3, an offshoot of Equation 2.5.6 can be transformed to Equation 2.6: $\Delta \mathrm{GDP}_{t}=\left\{\Delta \operatorname{lnHEALTH}_{t}, \Delta \operatorname{lnEDU}_{t}, \Delta \operatorname{lnFIN}{ }_{t}, \Delta \operatorname{lnINST}_{t}, \Delta \operatorname{lnINQ}_{t}, \Delta \operatorname{lnTO}_{t}, \Delta \operatorname{lnCO} 2_{t}, \Delta \operatorname{lnEC}{ }_{t}\right\} \ldots \ldots \ldots . .$. Equation 2. As a result, based on econometric form (matrix), the VECM model for the study can be represented in Equations 2.7 to 2.15:

$$
\begin{aligned}
& \mathrm{INQ}_{t}=\mathrm{a}_{1}+\mathrm{a}_{2} \operatorname{HEALTH}_{t}+\mathrm{a}_{3} \mathrm{EDU}_{t}+\mathrm{a}_{4} \mathrm{FIN}_{t}+\mathrm{a}_{5} \mathrm{INST}_{t}+\mathrm{a}_{6} \mathrm{GDP}_{t}+\mathrm{a}_{7} \mathrm{TO}_{t}+\mathrm{a}_{8} \mathrm{CO} 2_{t}+\mathrm{a}_{9} \mathrm{EC}_{t}+\varepsilon \ldots \ldots \text { Equation } 2.7 \\
& \text { HEALTH }_{t}=\mathrm{b}_{1}+\mathrm{b}_{2} \mathrm{GDP}_{t}+\mathrm{b}_{3} \mathrm{EDU}_{t}+\mathrm{b}_{4} \mathrm{FIN}_{t}+\mathrm{b}_{5} \mathrm{INST}_{t}+\mathrm{b}_{6} \mathrm{INQ}_{t}+\mathrm{b}_{7} \mathrm{TO}_{t}+\mathrm{b}_{8} \mathrm{CO}_{2}+\mathrm{b}_{9} \mathrm{EC}_{t}+\varepsilon . . \text { Equation } 2.8 \\
& \mathrm{EDU}_{t}=\mathrm{c} 1+\mathrm{c}_{2} \mathrm{GDP}_{t}+\mathrm{c}_{3} \mathrm{HEALTH}_{t}+\mathrm{c}_{4} \mathrm{FIN}_{t}+\mathrm{c}_{5} \mathrm{INST}_{t}+\mathrm{c}_{6} \mathrm{INQ}_{t}+\mathrm{c}_{7} \mathrm{TO}_{t}+\mathrm{c}_{8} \mathrm{CO}_{t}+\mathrm{c}_{9} \mathrm{EC}_{t}+\varepsilon \ldots \text { Equation } 2.9 \\
& \text { FIN }_{t}=\mathrm{d}_{1}+\mathrm{d}_{2} \mathrm{GDP}_{t}+\mathrm{d}_{3} \text { HEALTH }_{t}+\mathrm{d}_{4} \text { EDU }_{t}+\mathrm{d}_{5} \text { INST }_{t}+\mathrm{d}_{6} \mathrm{INQ}_{t}+\mathrm{d}_{7} \mathrm{TO}_{t}+\mathrm{d}_{8} \mathrm{CO}_{t}+\mathrm{d}_{9} \mathrm{EC}_{t}+\varepsilon . . \text { Equation } 2.10 \\
& \mathrm{INST}_{t}=\mathrm{e} 1+\mathrm{e}_{2} \mathrm{GDP}_{t}+\mathrm{e}_{3} \mathrm{HEALTH}_{t}+\mathrm{e}_{4} \mathrm{EDU}_{t}+\mathrm{e}_{5} \mathrm{FIN}_{t}+\mathrm{e}_{6} \mathrm{INQ}_{t}+\mathrm{e}_{7} \mathrm{TO}_{t}+\mathrm{e}_{8} \mathrm{CO}_{t}+\mathrm{e}_{9} \mathrm{EC}_{t}+\varepsilon . . \text { Equation } 2.11 \\
& \mathrm{GDP}_{t}=\mathrm{f} 1+\mathrm{f}_{2} \mathrm{INQ}_{t}+\mathrm{f}_{3} \mathrm{HEALTH}_{t}+\mathrm{f}_{4} \mathrm{EDU}_{t}+\mathrm{f}_{5} \mathrm{FIN}_{t}+\mathrm{f}_{6} \mathrm{INST}_{t}+\mathrm{f}_{7} \mathrm{TO}_{t}+\mathrm{f}_{8} \mathrm{CO}{ }_{t}+\mathrm{f}_{9} \mathrm{EC}_{t}+\varepsilon \ldots \ldots \ldots . . \text { Equation } 2.12 \\
& \mathrm{TO}_{t}=\mathrm{g}_{1}+\mathrm{g}_{2} \mathrm{GDP}_{t}+\mathrm{g}_{3} \mathrm{HEALTH}_{t}+\mathrm{g}_{4} \mathrm{EDU}_{t}+\mathrm{g}_{5} \mathrm{FIN}_{t}+\mathrm{g}_{6} \mathrm{INST}_{t}+\mathrm{g}_{7} \mathrm{INQ}_{t}+\mathrm{g}_{8} \mathrm{CO} 2{ }_{t}+\mathrm{g}_{9} \mathrm{EC}_{t}+\varepsilon . . \text { Equation } 2.13 \\
& \mathrm{CO}_{t}=\mathrm{h}_{1}+\mathrm{h}_{2} \mathrm{GDP}_{t}+\mathrm{h}_{3} \mathrm{HEALTH}_{t}+\mathrm{h}_{4} \mathrm{EDU}_{t}+\mathrm{h}_{5} \mathrm{FIN}_{t}+\mathrm{h}_{6} \mathrm{INST}_{t}+\mathrm{h}_{7} \mathrm{INQ}_{t}+\mathrm{h}_{8} \mathrm{TO}_{t}+\mathrm{h}_{9} \mathrm{EC}_{t}+\varepsilon . . \text { Equation } 2.14 \\
& \mathrm{EC}_{t}=\mathrm{i}_{1}+\mathrm{i}_{2} \mathrm{GDP}_{t}+\mathrm{i}_{3} \mathrm{HEALTH}_{t}+\mathrm{i}_{4} \mathrm{EDU}_{t}+\mathrm{i}_{5} \mathrm{FIN}_{t}+\mathrm{i}_{6} \mathrm{INST}_{t}+\mathrm{i}_{7} \mathrm{INQ}_{t}+\mathrm{i}_{8} \mathrm{TO}_{t}+\mathrm{i}_{9} \mathrm{CO}_{t}+\varepsilon \ldots \ldots \ldots \text { Equation } 2.15
\end{aligned}
$$

However, since socio-economic inequality (includes income inequality, gender inequality, racial or ethnic inequality, age inequality, and inequalities in health) is broader than income inequality and poverty, in that it is defined over the entire population, and does not only focus on the poor, hence a broader measure of socioeconomic inequality is recommended in the literature (Younsi \& Bechtini, 2018; Jamel \& Maktouf, 2017). Consequently, by applying the principal component technique on the five important proxies of socioeconomic inequalities, namely, Gini coefficient-income inequality (ranges from 0-perfect equality- to 1perfect inequality-), Atkinson index-a family of income inequality measures, Ratio of female to male labor force participation rate (\%) (Modeled ILO estimate), Unemployment, total (\% of the total labor force) (modeled ILO estimate), and refugee population by country or territory of origin, a composite socio-economic inequality index was constructed (see Appendix A) to generate our measure of trends in socioeconomic inequalities within the BRICS countries using a dataset from 1990 to 2019 (Younsi \& Bechtini, 2018; Jamel \& Maktouf, 2017). In Equations 7 to 15, GDP represents real per capita GDP (proxy for economic growth), HEALTH stands for total government expenditure on health (proxy for health development), and EDU is the weighted average of government expenditure in primary and secondary and tertiary education (proxy for educational development). Again, INST is institutional fitness, as represented by aggregations of economic, political and institutional indexes (Licumba, Dzator \& Zhang, 2016; Eggoh, Houeninvo \& Sossou, 2015; Adelowokan, 2012). FIN represents financial development, TO, is trade openness, C02 is environmental pollution, and EC represents Energy consumption.

The ' $\varepsilon$ ' represents the disturbance, while a1...a9 represents the unknown population parameters. The various measures of constructs are shown in Appendix E. However, socio-economic inequality (includes income inequality, gender inequality, racial or ethnic inequality, age inequality, and inequalities in health) is broader than income inequality and poverty. In that, it is defined over the entire population and does not only focus on the poor, hence a broader measure of male labor force participation rate (\%) (modeled ILO estimate), Unemployment, total (\% of the total labor force) (modeled ILO estimate), and refugee population by country or territory of origin, a composite socio-economic inequality index was constructed (see Appendix 2A) to generate our measure of trends in socioeconomic inequalities within the BRICS countries using a dataset 
from 1990 to 2019 (Younsi \& Bechtini, 2018; Jamel \& Maktouf, 2017). Specifically, the construction of the composite socio-economic inequality index for all the countries was done by applying principal component analysis (PCA) on our five measures of socio-economic inequality (Younsi \& Bechtini, 2018).

The PCA as a multivariate statistical technique is usually used for analyzing the inter-correlation by linking several quantitative variables (Younsi \& Bechtini, 2018; Adelowokan, 2012; Strittmatter \& Sunde, 2011). For each dataset with ' $p$ ' quantitative variables, we can evaluate at most $p$ principal components (PC) by descending order of the eigenvalues, with each ' $p$ ' representing a linear combination of the original variables, and the coefficients equal to the eigenvectors of the correlation covariance matrix (Younsi \& Bechtini, 2018; Jamel \& Maktouf, 2017). The results of the constructed composite socio-economic index for the five BRICS countries, as depicted in Appendix 2A, shows the PC analysis for Brazil, Russia, India, China, and South Africa with the highest first PC explains about 58.13\%, 57.34\%, 60.42\%, 64.69\%, and 70.93\% of the standardized variance in each of the countries, respectively; hence, were selected to compute the socio-economic index (Younsi \& Bechtini, 2018). This was based on the premise that the first PC is a linear combination of the whole five measures of socio-economic sustainability index with the respective weights represented by the first eigenvector (Younsi \& Bechtini, 2018). Consequently, 78.34\%, 78.52\%, 39.67\%, 41.45\% and 32.15\% individual contributions for each of the GCII; AI, RFMLF, UNEMP, and RPOP respectively were further used to construct the socio-economic index for Brazil.

After rescaling to the standardized variance of the first PC (Younsi \& Bechtini, 2018; Jamel \& Maktouf, 2017; De Bruyn et al., 1998). Again, the same interpretations of results were seen to be true for the other four countries in our analysis (Russia, India, China and South Africa). One major assumption for the study was the fact that all explanatory variables are expected to have fixed values in repeated samples; we also expected each $(\varepsilon)$ disturbance to be normally distributed, while we also posit the absence of perfect multicollinearity (Asteriou \& Hall, 2007). Consequently, the joint effect of all determinants on socio-economic inequality was tested via Equation 2.7 (Lee \& Tan, 2006; Akaike, 1974). Additionally, based on a methodology adopted in Jamel \& Maktouf (2017) and Maryam et al. (2017), our last model (Equation 2.15) also seeks to confirm/refute the following hypotheses: Neutrality Hypothesis (of no causality - in either direction between energy consumption and economic growth), Energy Conservation Hypothesis (of evidence of unidirectional causality running from economic growth to energy consumption), Growth Hypothesis (of energy consumption drives economic growth), and Feedback Hypothesis (of a bidirectional causal relationship between energy consumption and economic growth). Consequently, the following steps were followed:

Assumptions and Diagnostics Tests: After satisfying with the level of measurement and sample size, we tested for conformity with the assumptions of normality, linearity independence of errors and homoscedasticity. Again, collinearity (testing for multicollinearity) and casewise diagnostics (to identify outliers) were also tested. There is also a need to check for spurious results where the Durban Watson Statistic is less than the R-square of the model (Maktouf, 2017).

Unit Root Test: A unit root test is usually conducted to identify non-stationarity, that is, the presence of unitroots. This was performed via the Standard ADF Test, Phillips-Perron (PP) Test, and KPSS-KwiatkowskiPhillips-Schmidt-Shin Test at various differenced series (Awolusi, 2019; Asteriou \& Hall, 2007). The ADF hypothesis both null hypothesis (Ho: Model has a Unit Root) and an alternative hypothesis $\left(\mathrm{H}_{1}\right.$ : Model has no Unit Root). If the critical value is greater than the computed result, then, the null hypothesis rejects, signifying the absence of unit root (Maktouf, 2017). Similarly, in the PP test, the null hypothesis (Ho: Model has a Unit Root) is rejected if the critical value (in absolute value) than the computed result (Hussin et al., 2012). Alternatively, KPSS-Kwiatkowski-Phillips-Schmidt-Shin Test merely hypothesizes a null hypothesis that the model is stationary (Ho: Model is stationary) and an alternative hypothesis ( $\mathrm{H}_{1}$ : Model is not stationary).

Multivariate Co-Integration Analysis: After establishing the stationarity of our variables, we proceeded to test the extent of cointegration, using the Johansen Multivariate Cointegration test (Johansen's Trace and Max Eigenvalue tests) at various level of significance (Hussin et al., 2012; Asteriou \& Hall, 2007). Out of the two Johansen's Trace and Max Eigenvalue tests, the ranking was dependent on the Trace test results, due to the fact that trace test often shows more robustness to both excess kurtoses in the residual and skewness (Hussin 
et al., 2012). Appropriately, the test provided information on whether socio-economic inequality and economic growth are tied together in the long run (Hussin et al., 2012).

Vector Error Correction Model-VECM: VECM was then performed to show the route/direction of causality (Lee \& Tan, 2006). While the short term Granger causal relationship was observed through the Wald test (F statistics), our long-run Granger causal relationship was determined based on the value of error correction term-ECT-1 to identify the existence and nature of the causality relationship between the variables (Younsi \& Bechtini, 2018; Javeria et al, 2017; Awosusi \& Awolusi, 2014). After selecting the appropriate models using Hussin et al.'s (2012) criterion, the optimal lag length was determined next. Unfortunately, automatic lag length selection is not possible in E-Views software, hence, we estimated the models for a few lags and later, reduced down to check for the SBC and AIC optimal value (Asteriou \& Hall, 2007). However, since cointegration merely indicates the absence or presence of Granger-causality, without showing the route of causality, hence, the direction was decided via VECM (Hussin et al., 2012; Lee \& Tan, 2006).

\section{Presentation and Discussion of Results}

Similar to previous studies (Younsi \& Bechtini, 2018; Jamel \& Maktouf, 2017), this study tested for validity and reliability of our data sets by ascertaining conformity with few diagnostic tests and assumptions of multiple regression via Equation 2.7, with socio-economic inequality as dependent variables, economic growth as the independent variable, while holding other variables (FIN, Health, EDU, INST, TO, CO2, EC) as control variables. First, we ran the script to test for normality of our dependent variable (log of inequality) and obtained a skewness and kurtosis of -0.093 and -0.677 with all satisfying the criteria for a normal distribution (between -1.0 and +1.0) (Adelakun, 2011; Akinola \& Bokana, 2017). The same goes for other independent and control variables. Secondly, we ran various scripts to test linearity assumptions between (1) dependent variable and independent variables (2) dependent variable and our control variables.

For the linearity test between the log of socio-economic inequality and economic growth variables, we obtained statistically significant values $(\mathrm{r}=0.577, \mathrm{p}<0.001)$, meaning a linear relationship exists between these variables (Adelakun, 2011; Akinola \& Bokana, 2017). Moreover, our test for homogeneity of variance assumption via the Levene test showed that the probability associated with the test $(0.712)$ was $p=0.477$, greater than the 0.01 level of significance required to test the assumption (Agrawal, 2015; Akinola \& Bokana, 2017). Hence, the null hypothesis of equal variances was not rejected (Akinola \& Bokana, 2017). Finally, all major diagnostic tests: collinearity diagnostics for testing multicollinearity, casewise diagnostics to identify outliers and Durbin-Watson statistics to test for serial correlation showed a minimum/maximum standardized residuals of -2.772 (fell in the acceptable range of +- 3.0), Durbin-Watson statistic of 1.983 (which falls within the acceptable range since the residuals are not correlated at statistics, approximately 2) (Adelakun, 2011; Adelowokan, 2012; Agrawal, 2015).

Unit Root Test: The Augmented Dickey-Fuller (ADF) test was conducted for unit roots in both first difference and levels for all the selected countries (Awolusi \& Mbonigaba, 2020; Kautsiro \& Awolusi, 2020). The result of this analysis is reported in Appendix 2B(i). The result showed consistency by not accepting the null hypothesis at the $1 \%, 5 \%$ and $10 \%$ levels of significance. Similar to our ADF results, the PP test was also conducted for unit roots in both first difference and levels for all the selected countries, and the results also, as reported in Appendix 2B(ii) also assumed stationarity of the series by the rejection of the null hypothesis, when the test statistic is less than the $1 \%, 5 \%$ and $10 \%$ levels of significance (Hussin et al., 2012). Lastly, the KPSS-Kwiatkowski-Phillips-Schmidt-Shin Test (as shown in Appendix 2Biii) for each of the selected countries, also conducted in the levels and first difference via the Newey-West bandwidth method (Lee \& Tan, 2006), however, rejected the null hypothesis only at levels unlike previous tests (ADF and PP tests). This test (KPSS) further confirmed the level of integration for all variables (Maktouf, 2017).

Results for Multiple Co-Integrating Vectors: The long-run equilibrium relationships among socio-economic inequality, economic growth and other determinants in all the selected countries were tested using multivariate co-integration (Zha et al., 2019; Johansen \& Juselius, 1990). The results as shown in Appendix 2C were extracted using the likelihood ratio test, after a series of selection processes with a 1 through 4 lag length. The results basically posit the existence of co-integrating vectors in all the models. Specifically, there 
were 3 vectors in the Brazilian, Russian, Chinese and South African systems (at a lag interval of 1 to 2), while four co-integrating vectors were experienced in India's models (lag length of 1 to 3) (Asteriou \& Hall, 2007). This implied that while the variables in Brazil, Russia, China and South Africa have long-run equilibrium relationships and were adjusting via three identified channels in the short-run, our model for India's variables did the same adjustment through four channels (Maktouf, 2017; Asteriou \& Hall, 2007). However, since it is common in literature for the estimated test statistics to show different results, the ranking was done based on the Trace test results due to the robustness of the Trace test results to both skewness and excess kurtosis (Maktouf, 2017; Hussin et al., 2012; Asteriou \& Hall, 2007).

Result of Vector Error Correction Modelling via Granger Causality: The Granger causality test was conducted to test the short-term effect of economic growth on socio-economic inequality within the BRICS countries. VECM was conducted for each system (country) and the various null hypotheses $\left(\mathrm{H}_{0}\right.$ : There is no impact of ' $\mathrm{X}$ ' on ' $\mathrm{Y}$ ') was tested at different constants and levels of significance (1\%,5\%, and 10\%) - for both the explanatory variables and the 'group' long-run error terms (ECT $t_{t-1}$ terms). The results of this analysis for each of the five BRICS countries are reported in Tables 1 to 5.

Table 1: VECM Results for Brazil ( $\mathrm{p}=2)$

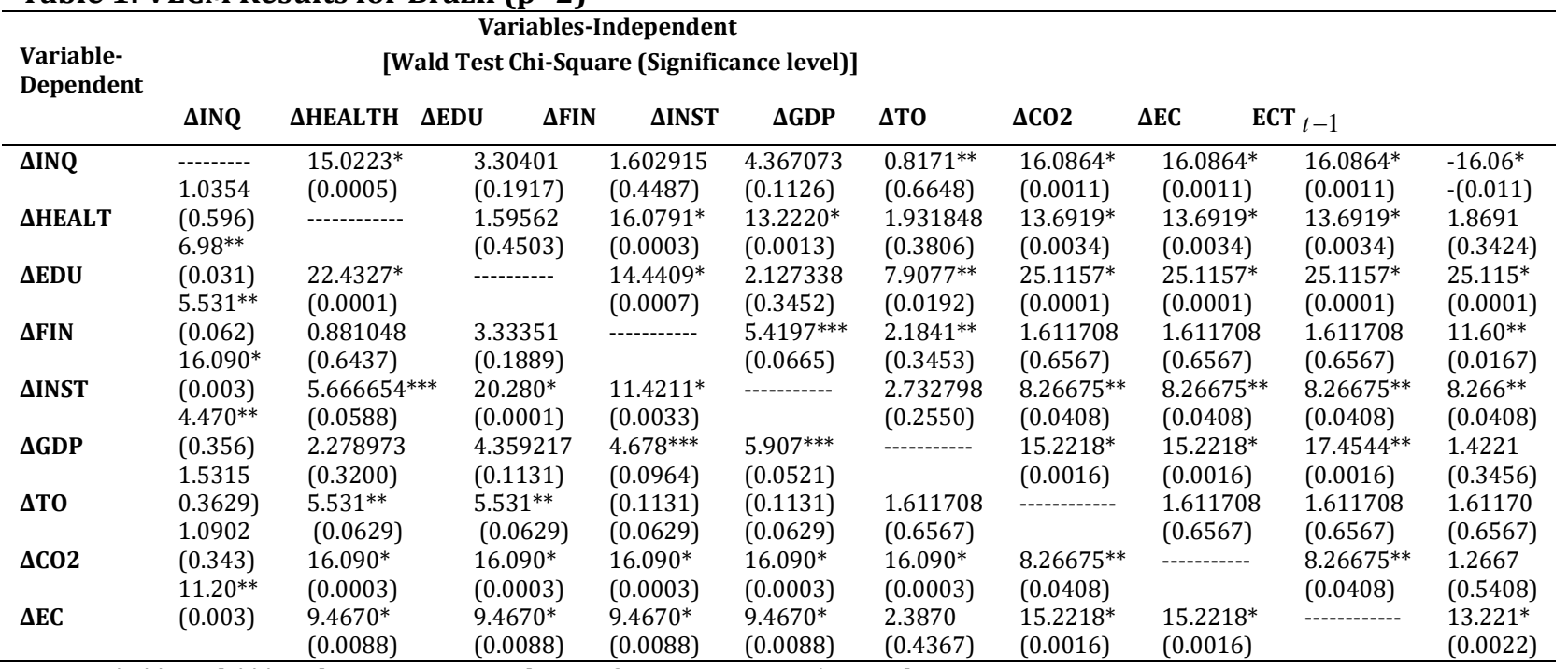

Note: $* * *$ and $* * *$ indicate statistical significance at $1 \%, 5 \%$ and $10 \%$.

The Brazilian, Russian, Chinese and South African systems consist of three co-integrating vectors. Consequently, a Wald test (joint) was carried out on each of the three error correction terms. However, the Indian model exhibited four co-integrating vectors; consequently, a Wald test (joint) was also carried out on each of the four error correction terms (Younsi \& Bechtini, 2018; Javeria et al., 2017). The Wald test ChiSquare result for all the five countries showed a causal effect in the short run. These effects were both running bi-directionally and unidirectionally for all the countries. 
Table 2: VECM Results for Russia $(p=2)$

Variables-Independent

Variable-

[Wald Test Chi-Square (Significance level)]

\begin{tabular}{|c|c|c|c|c|c|c|c|c|c|c|}
\hline Dependent & $\Delta \mathrm{INQ}$ & $\triangle$ HEALTH & $\Delta E D U$ & $\Delta \mathrm{INST}$ & $\Delta$ GDP & $\Delta \mathrm{TO}$ & $\Delta \mathrm{CO} 2$ & $\Delta \mathbf{E C}$ & $\mathbf{T}_{t-1}$ & \\
\hline \multirow[t]{2}{*}{$\Delta \mathrm{INQ}$} & ---- & $8.207869^{* *}$ & 1.961350 & 18.30197* & 1.622662 & 5.350815 & 19.9355* & 19.9355* & 19.9355* & $-19.355^{*}$ \\
\hline & & 0.0419 & 0.5805 & 0.0004 & 0.6543 & 0.1478 & 0.0002 & 0.0002 & 0.0002 & -0.0044 \\
\hline \multirow[t]{2}{*}{ DHEALT } & 3.8608 & -------- & 1.510704 & $16.92722^{*}$ & 2.403152 & 5.888746 & $24.9819 *$ & $24.9819^{*}$ & $24.9819^{*}$ & 2.9819 \\
\hline & 0.22365 & & 0.6798 & 0.0007 & 0.4930 & 0.1172 & 0.00001 & 0.00001 & 0.00001 & 0.43201 \\
\hline \multirow[t]{2}{*}{$\Delta$ EDU } & 1.54305 & $6.59030^{* * *}$ & --.---- & 3.373826 & $8.3045^{* *}$ & $10.526^{* *}$ & $10.526^{* *}$ & $10.526^{* *}$ & $10.526^{* *}$ & $10.526^{* *}$ \\
\hline & 0.6724 & 0.0862 & & 0.3375 & 0.0401 & 0.0146 & 0.0146 & 0.0146 & 0.0146 & 0.0146 \\
\hline$\Delta$ FIN & $48.721^{*}$ & $9.798834^{* *}$ & $9.3608^{* *}$ & ------ & $24.7488^{*}$ & $8.5058^{* *}$ & $13.8349 *$ & 13.8349* & $13.8349^{*}$ & $13.8349 *$ \\
\hline \multirow[t]{2}{*}{$\Delta \mathrm{INST}$} & 0.66981 & $8.644371^{* *}$ & 4.853424 & $20.29062 *$ & ------ & $9.9160 * *$ & $37.0155^{*}$ & $37.0155^{*}$ & $37.0155^{*}$ & $37.0155^{*}$ \\
\hline & 0.8805 & 0.0344 & 0.1829 & 0.0001 & & 0.0193 & 0.0001 & 0.0001 & 0.0001 & 0.0001 \\
\hline \multirow[t]{2}{*}{$\Delta$ GDP } & 5.45319 & $9.565928^{* *}$ & 3.713398 & $17.45746^{*}$ & 2.028492 & ------ & $28.5783^{*}$ & $28.5783^{*}$ & $25.53764^{* *}$ & 2.5783 \\
\hline & 0.1414 & 0.0226 & 0.2941 & 0.0006 & 0.5665 & & 0.0001 & 0.0001 & 0.00121 & 0.4321 \\
\hline \multirow[t]{2}{*}{$\Delta \mathrm{TO}$} & $48.771^{*}$ & $48.7271^{*}$ & 48.7271* & $48.7271^{*}$ & $48.7271 *$ & $48.7271^{*}$ & ---------- & $13.8349 *$ & $13.8349^{*}$ & 1.8349 \\
\hline & 0.00001 & 0.00001 & 0.00001 & 0.00001 & 0.00001 & 0.00001 & & 0.4321 & 0.4321 & 0.1321 \\
\hline \multirow[t]{2}{*}{$\Delta \mathrm{CO} 2$} & 0.66981 & 0.668981 & 0.668981 & 0.668981 & 0.668981 & 0.668981 & $37.0155^{*}$ & --------- & $37.0155^{*}$ & 3.01343 \\
\hline & 0.8805 & 0.8805 & 0.8805 & 0.8805 & 0.8805 & 0.8805 & 0.0001 & & 0.0001 & 0.23481 \\
\hline
\end{tabular}

Note: $*, * *$ and $* * *$ indicate statistical significance at $1 \%, 5 \%$ and $10 \%$.

In Tables 1 to 5, we observed that for the Brazilian, Russian, and Chinese models, respectively, the influence of economic growth on socio-economic inequality was insignificant. Surprisingly, these results are somewhat different from previous results in the BRICS region (Younsi and Bechtini, 2018; Menon, 2017; Javeria et al., 2017; Jamel \& Maktouf, 2017).

Table 3: VECM Results for China $(p=2)$

Variables-Independent

[Wald Test Chi-Square (Significance level)]

\begin{tabular}{|c|c|c|c|c|c|c|c|c|c|c|}
\hline Dependent & $\Delta I N Q$ & $\Delta$ HEALTH $\triangle$ ED & $\Delta$ FIN & $\Delta$ INST & $\Delta G D P$ & $\Delta \mathrm{TO}$ & $\Delta \mathrm{CO2}$ & $\Delta \mathrm{EC}$ & $t-1$ & \\
\hline \multirow[t]{2}{*}{$\Delta \mathrm{INQ}$} & ---- & $9.34586^{* *}$ & 2.22230 & 13.45197* & 1.98733 & 3.42335 & $20.3455^{*}$ & $20.3455^{*}$ & $20.3455^{*}$ & $-20.355^{*}$ \\
\hline & & 0.0487 & 0.4564 & 0.0034 & 0.6653 & 0.2333 & 0.0032 & 0.0032 & 0.0032 & -0.0032 \\
\hline \multirow[t]{2}{*}{$\triangle$ HEALT } & $9.2222^{* *}$ & -------- & 4.456704 & $15.722^{*}$ & 2.43332 & 5.565446 & $22.4419^{*}$ & $22.4419 *$ & $22.4419^{*}$ & $24.5519 *$ \\
\hline & 0.0555 & & 0.3566 & 0.0347 & 0.3478 & 0.1567 & 0.0011 & 0.0011 & 0.0011 & 0.0011 \\
\hline \multirow[t]{2}{*}{$\Delta E D U$} & 1.678945 & $9.76530 * *$ & ------ & 3.567826 & $9.3045^{* *}$ & $10.526^{* *}$ & $11.236^{* *}$ & $11.236^{* *}$ & $11.236^{* *}$ & $13.346^{* *}$ \\
\hline & 0.7895 & 0.08062 & & 0.3564 & 0.0444 & 0.0433 & 0.0246 & 0.0246 & 0.0246 & 0.0246 \\
\hline \multirow[t]{2}{*}{$\Delta$ FIN } & $38.5671^{*}$ & $10.798876^{* *}$ & $9.5558 * *$ & ------- & $24.7488^{*}$ & $8.5058^{* *}$ & $51.335^{*}$ & $51.335^{*}$ & $51.335^{*}$ & $21.565^{*}$ \\
\hline & 0.00331 & 0.03456 & 0.0256 & & 0.00331 & 0.0455 & 0.00221 & 0.00221 & 0.00221 & 0.00221 \\
\hline \multirow[t]{2}{*}{$\Delta$ INST } & 0.54381 & $9.78971^{* *}$ & 4.65544 & $21.3462^{* *}$ & ------ & $9.9160^{* *}$ & $27.0995^{*}$ & $27.0995^{*}$ & $27.0995^{*}$ & $27.0995^{*}$ \\
\hline & 0.6645 & 0.0454 & 0.1829 & 0.0331 & & 0.0373 & 0.00101 & 0.00101 & 0.00101 & 0.00101 \\
\hline \multirow[t]{2}{*}{$\Delta$ GDP } & 3.35625 & $12.8765^{* *}$ & 3.54398 & $19.4576^{* *}$ & 2.78692 & ---.-- & $22.3443^{*}$ & $22.3443^{*}$ & $21.2345^{* *}$ & 2.3443 \\
\hline & 0.36257 & 0.0245 & 0.2561 & 0.0236 & 0.5555 & & 0.00122 & 0.00122 & 0.00134 & 0.4382 \\
\hline \multirow[t]{2}{*}{$\Delta \mathrm{TO}$} & $38.5671^{*}$ & $38.5671^{*}$ & $38.5671^{*}$ & $38.5671^{*}$ & $38.5671^{*}$ & $38.5671^{*}$ & ---------. & $51.335^{*}$ & $51.335^{*}$ & 1.43675 \\
\hline & 0.00331 & 0.00331 & 0.00331 & 0.00331 & 0.00331 & 0.00331 & & 0.00221 & 0.00221 & 0.3421 \\
\hline \multirow[t]{2}{*}{$\Delta \mathrm{CO} 2$} & 0.54381 & 0.54381 & 0.54381 & 0.54381 & 0.54381 & 0.54381 & $27.0995^{*}$ & ------- & $27.0995^{*}$ & -2.0995 \\
\hline & 0.6645 & 0.6645 & 0.6645 & 0.6645 & 0.6645 & 0.6645 & 0.00101 & & 0.00101 & -0.2301 \\
\hline \multirow[t]{2}{*}{$\Delta \mathrm{EC}$} & 2.48999 & 2.48999 & 2.48999 & 2.48999 & 2.48999 & 3.5374 & $22.3443^{*}$ & $22.3443^{*}$ & ------- & $22.3443^{*}$ \\
\hline & 0.2544 & 0.2544 & 0.2544 & 0.2544 & 0.2544 & 0.34653 & 0.00122 & 0.00122 & & 0.00122 \\
\hline
\end{tabular}

Note: $* * *$ and $* * *$ indicate statistical significance at $1 \%, 5 \%$ and $10 \%$. 
Table 4: VECM Results for India $(\mathrm{p}=2)$

Variables-Independent

Variable-

[Wald Test Chi-Square (Significance level)]

\begin{tabular}{|c|c|c|c|c|c|c|c|c|c|c|}
\hline Dependent & $\Delta I N Q$ & $\triangle$ HEALTH $\Delta$ & $\Delta E D U$ & $\Delta \mathrm{INST}$ & $\Delta$ GDP & $\Delta \mathrm{TO}$ & $\Delta \mathrm{CO} 2$ & $\triangle \mathrm{EC} \quad$ ECT & -1 & \\
\hline \multirow[t]{2}{*}{$\Delta \mathrm{INQ}$} & ----- & 1.34503 & $11.2456^{*}$ & $8.45682^{* *}$ & $11.6264^{* *}$ & $2.3418^{* *}$ & $23.444^{*}$ & $23.444^{*}$ & $23.444^{*}$ & $23.444^{*}$ \\
\hline & & 0.7775 & 0.00231 & 0.0734 & 0.0339 & 0.4448 & 0.0034 & 0.0034 & 0.0034 & 0.0034 \\
\hline \multirow[t]{2}{*}{$\triangle$ HEALT } & 3.47675 & ------ & $15.2405^{*}$ & $23.3435^{*}$ & $13.446^{*}$ & $11.443^{* *}$ & $25.288^{*}$ & $25.288^{*}$ & $25.288^{*}$ & 2.6588 \\
\hline & 0.2347 & & 0.00221 & 0.00491 & 0.00227 & 0.0476 & 0.00341 & 0.00341 & 0.00341 & 0.45241 \\
\hline \multirow[t]{2}{*}{$\Delta E D U$} & 2.498794 & $19.4442^{*}$ & ----- & $17.34511^{\text {*** }}$ & 2.13333 & $9.999 * * *$ & $20.9914^{*}$ & $20.9914^{*}$ & $20.994^{*}$ & $20.994^{*}$ \\
\hline & 0.43877 & 0.0028 & & 0.0567 & 0.4534 & 0.0766 & 0.00331 & 0.00331 & 0.00331 & 0.00331 \\
\hline \multirow[t]{2}{*}{$\Delta$ FIN } & 2.99743 & 1.45294 & 4.34551 & ----- & 4.24226 & 1.56774 & 4.62592 & 4.62592 & 4.62592 & $14.622^{* *}$ \\
\hline & 0.6490 & 0.45382 & 0.3456 & & 0.2432 & 0.3431 & 0.4481 & 0.4481 & 0.4481 & 0.00481 \\
\hline \multirow[t]{2}{*}{$\Delta$ INST } & $10.348^{* *}$ & 2.45633 & $23.345^{*}$ & $11.5667 *$ & ------- & $15.111^{*}$ & $22.961^{*}$ & $22.961^{*}$ & $22.961^{*}$ & $22.234^{*}$ \\
\hline & 0.0652 & 0.3429 & 0.00231 & 0.00347 & & 0.00447 & 0.00341 & 0.00341 & 0.00341 & 0.00245 \\
\hline \multirow[t]{2}{*}{$\Delta$ GDP } & $13.4258^{* *}$ & $12.3451^{* *}$ & 2.34535 & 2.45674 & $8.554^{* * *}$ & -------- & $15.665^{*}$ & $15.665^{*}$ & $15.665^{*}$ & $15.665^{*}$ \\
\hline & 0.02353 & 0.0420 & 0.4349 & 0.4564 & 0.0779 & & 0.0036 & 0.0036 & 0.0036 & 0.0036 \\
\hline \multirow[t]{2}{*}{$\Delta \mathrm{TO}$} & 2.99743 & 2.99743 & 2.99743 & 2.99743 & 2.99743 & 2.99743 & ---------. & 4.62592 & 4.62592 & 4.62592 \\
\hline & 0.6490 & 0.6490 & 0.6490 & 0.6490 & 0.6490 & 0.6490 & & 0.4481 & 0.4481 & 0.4481 \\
\hline \multirow[t]{2}{*}{$\Delta \mathrm{CO} 2$} & $10.348^{* *}$ & $10.348^{* *}$ & $10.348^{* *}$ & $10.348^{* *}$ & $10.348^{* *}$ & $10.348^{* *}$ & $22.961^{*}$ & ------- & $22.961^{*}$ & 2.9623 \\
\hline & 0.0652 & 0.0652 & 0.0652 & 0.0652 & 0.0652 & 0.0652 & 0.00341 & & 0.00341 & 0.34341 \\
\hline \multirow[t]{2}{*}{$\Delta \mathbf{E C}$} & $11.348^{* *}$ & $11.448^{* *}$ & $11.3448^{* *}$ & $11.3448^{* *}$ & $11.348^{* *}$ & 1.344 & $15.665^{*}$ & $15.665^{*}$ & ---------. & $15.665^{*}$ \\
\hline & 0.0443 & 0.0443 & 0.0443 & 0.0443 & 0.0443 & 0.63587 & 0.0036 & 0.0036 & & 0.0036 \\
\hline
\end{tabular}

Note: ${ }^{*}{ }^{* *}$ and ${ }^{* * *}$ indicate statistical significance at $1 \%, 5 \%$ and $10 \%$.

Unfortunately, our study observed a unidirectional causality between economic growth and socio-economic inequality in both India and South Africa. However, unlike our estimates from Brazil, India and South Africa's models (reverse causality), findings from the Granger causality test depict a unidirectional causality from financial developments to income inequality. These interesting results may be likened to a seemly presence of the "resource curse" in the two countries, as opposed to previous studies on BRICS countries (Younsi \& Bechtini, 2018; Javeria et al., 2017; Jamel \& Maktouf, 2017).

Table 5: VECM Results for South Africa $(\mathrm{p}=2)$

Variables-Independent

Variable-

Dependent [Wald Test Chi-Square (Significance level)]

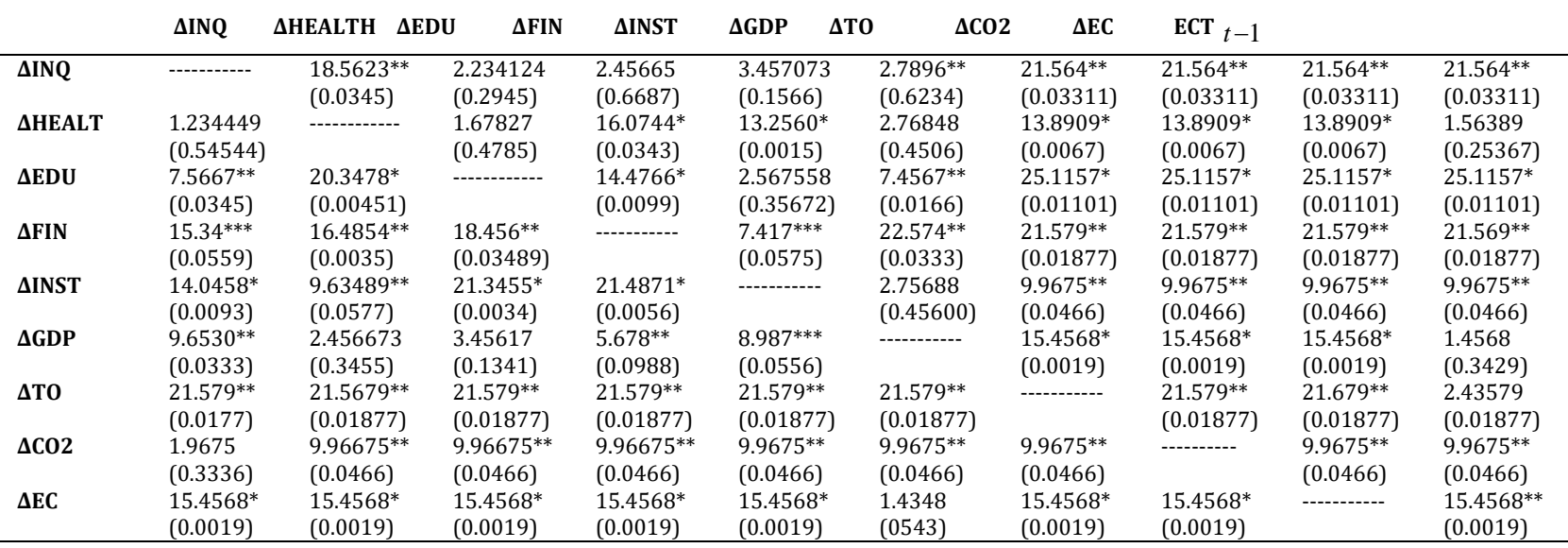

Note: ${ }^{*}, * *$ and ${ }^{* * *}$ indicate statistical significance at $1 \%, 5 \%$ and $10 \%$

In all our models, educational development, financial development, institutional fitness, and energy consumption seem to contribute to socio-economic inequality in all the BRICS countries. However, due to the strong unidirectional causal relationships between economic growth and socio-economic inequality in Brazil, India and South Africa, it is interesting to know that poor institutional fitness, education, financial development and energy consumption may have altered the influence of economic growth in the three countries over the years (Younsi \& Bechtini, 2018; Javeria et al., 2017; Jamel \& Maktouf, 2017). Additionally, our study also confirmed the following hypotheses: Neutrality Hypothesis of no causality - in either direction 
- between energy consumption and economic growth (None); Energy Conservation Hypothesis of evidence of unidirectional causality running from economic growth to energy consumption (In all the models); Growth Hypothesis of energy consumption drives economic growth (In the model of Russia), and Feedback Hypothesis (of a bidirectional causal relationship between energy consumption and economic growth.

Lastly, the short term Granger Causal relationship was observed through the Wald test (F statistics) on a group, of the related coefficients, and we observed that most variables of EDU (educational development), FIN (financial development), INST (institutional fitness) and EC (energy consumptions) are the short term Granger cause for INQ (socio-economic inequality). This means the levels of socio-economic inequalities in the short term are mainly influenced by the levels of educational development, financial development, institutional fitness and energy consumptions whereas other variables do not exhibit significant relationships. This finding is also somewhat similar to previous research findings (Younsi and Bechtini, 2018; Menon, 2017; Bittencourt, 2010; Giri and Sehrawat, 2015; Hye, 2011; Odhiambo, 2010), both on the effect of economic growth on socio-economic sustainability (inequality), as well as, the negative influence of poor financial development and low energy consumption as the short term Granger cause for socio-economic inequality (Azevedo et al., 2018; Younsi \& Bechtini, 2018). Specifically, Younsi and Bechtini (2018) study on the relationships between economic growth and socio-economic inequality in BRICS countries using annual panel data covering the period 1995-2015 also confirmed a long-run cointegration relationship between economic growth and income inequality in the BRICS countries. While estimates from fixed effects results posit the positive and significant influence of economic growth on income inequality, the coefficient of its squared term depicts a significant negative effect.

Similar to what the present study observed in Brazil, India and South Africa estimates. But there was no reversed causal relationship between income inequality and economic growth in Younsi and Bechtini's (2018) study. Consequently, mixed policy options aimed at reducing inequality in the BRICS bloc could be achieved through improvements in taxation and financial system policies (Younsi and Bechtini, 2018; Menon, 2017). In addition, similar to the present study, while emphasizing the role of economic growth on socioeconomic redistribution in many developing economies, Menon's (2017) study also established negative trends in the estimates for South Africa but differed based on our improved estimates for China. Consequently, South Africa should concentrate on enacting policies to reduce inflation via proper monitoring of monetary control and domestic products (Menon, 2017). Furthermore, our estimated results for both China and Russia on the influence of economic growth on socio-economic sustainability in the BRICS countries can also be demonstrated by the Kuznets hypothesis, which posits for an increase in income disparities arising from the first phase of economic growth, while the same economic growth in a later phase, given redistribution mechanisms, tends to contribute to the attainment of an egalitarian pattern of income distribution in a welfare state (Fan \& Zheng, 2013; Omer, 2008; Spangenberg, 2004).

Robustness Checks: Our main robustness check was to consider the inclusion of additional variables, such as exchange rate volatility and inflation risk, and then re-estimated Equation 7 via GMM estimators and pooled ordinary least square (POLS) (Akinola \& Bokana, 2017; Menon, 2017; Blundell and Bond, 1998; Arellano and Bond, 1991). Similar to a study by Blundell and Bond (1998) and Arellano and Bond (1991), we selected two specific diagnostic tests, Hansen test and the second-order autocorrelation AR (2) test, to test for any probable over-identifying restrictions and serial correlations of the error terms, respectively. The results of our GMM estimators are shown in Appendix 2D. Estimates of the GMM and POLS largely attested to the robustness of our main preferred results due to the unchanged signs and level of significance (mostly 1 and 5 percent). Again, the results of both the GMM and POLS in the new samples (with additional regressors) are similar to the main finding of this study, which concluded that the influence of economic growth on socioeconomic inequality was largely insignificant. Specifically, in our GMM results, the Hansen test for overidentification indicates the acceptance of the null hypothesis, while the AR (2) test estimate also indicates the presence of a second-order serial correlation in our mode (Menon, 2017). Hence, a validation of our instruments and seemly uncorrelated with the error term (Akinola \& Bokana, 2017). In particular, the robustness analysis posits similarity in sign and magnitude as in our main results in Tables 1 - 5 . 


\section{Conclusion and Implications of Study}

Conclusion: This paper examined the influence of economic growth on socio-economic inequality within the BRICS countries from 1990 to 2019. The long-run equilibrium relationships were tested via a multivariate cointegration technique by Johansen and Juselius (Johansen \& Juselius, 1990). Our results confirmed the existence of co-integrating vectors in all the models of all the selected BRICS countries. Specifically, estimates from the models of Brazil, Russia, China and South Africa posit a long-run equilibrium relationship with each other but did the adjustment in the short-run via three established channels. On the other hand, variables in the models of India also exhibit the same adjustment via four identified channels. Unfortunately, since the presence of cointegrating vectors in any system merely assumed the existence and/or nonexistence of causality, this, however, often failed to specify the route of causality among the systems. Consequently, the outcome of the estimated causality test detected both unidirectionally and bidirectionally causal effects in the short run for all the variables. Our study, therefore, concluded that the long-run equilibrium relationships between economic growth and socio-economic inequalities in the BRICS countries vary from one country to another, but were largely insignificant. Specifically, we observed that for the Brazilian, Russian, and Chinese models, respectively, the influence of economic growth on socio-economic inequality was insignificant.

Surprisingly, our study observed a unidirectional causality between economic growth and socio-economic inequality in both India and South Africa. These interesting results may be likened to a seemly presence of a "resource curse" in the two countries, as opposed to previous studies in the same bloc (Younsi \& Bechtini, 2018; Javeria et al., 2017; Jamel \& Maktouf, 2017). In conclusion, the present study found that common policy options were not possible and that for the block to pursue its economic prosperity goals without compromising individual countries' needs for socioeconomic sustainability, varied policy options were inevitable. Additionally, although our study failed to confirm Neutrality Hypothesis, we, however, confirmed the presence of the Energy Conservation Hypothesis (In all the models); Growth Hypothesis (In the model of Russia), and Feedback Hypothesis (In the model of Russia). Lastly, the study observed that in the short term Granger Causal relationships, variables of educational development, financial development, institutional fitness and energy consumption are majorly the short term Granger cause for socio-economic inequality. Finally, all the variables in each model adjusted to equilibrium in the long run, except for trade openness and C02 emissions in virtually all the BRICS systems. This proves that trade openness and C02 emissions are not valid variables to predict changes in socio-economic inequality in the BRICS countries.

Policy Implications and Recommendations: Our findings have shown that socio-economic inequality (sustainability) has not been adequately supported, while there are variations in the impact of economic growth on socio-economic inequalities within the BRICS bloc. Our findings seem to be tacit support for the "resource course" problem in the three countries (Brazil, India, and South Africa). Consequently, this study posits for a more radical policy mix to reduce the negative impact of economic growth on socioeconomic inequality in the three (Brazil, India and South Africa) countries. The policies should focus more on radical law reforms and independent organizations; population growth control, speedy poverty alleviation and basic education; enhanced social programs; market development; Integration of existing policies and creation of societal culture. To achieve any radical legal basis for the transition from natural resource export, as well as sweeping regulation for the sustainable usage of natural resources protection. Strict penalties on violations of environment-related law. General country-wide support should be implemented in Brazil, India and South Africa. In addition, there may be an urgent need to define the active role of NGOs and other independent institutions in promoting socioeconomic equality (sustainability) practices at both local and national levels. Specifically, in South Africa, adequate Corporate Social Responsibility (CSR) guidelines should be implemented as a veritable way of encouraging corporations.

To monitor their contributions to socio-economic sustainability at both local and national levels. Special enforcement mechanism, such as "Green Scorpions" should be adequately empowered by the coordinating ministry (Ministry of Environment and Tourism), in an effort to step up their monitoring, assessment and enforcement roles. There is also a need to have a national standard for reporting CSR by corporations and civil society organizations (CSOs). In addition, the increasing trends in socioeconomic inequalities in Brazil, India, and South Africa require a radical policy mix on population growth control, inclusive and basic education for all citizens, as well as, swift poverty alleviation programs. There is an urgent need for improved 
transparency and participation of media organizations in this regard. The establishment and promotion of nationwide social standards and corporate social responsibility guidelines will also go a long way in reducing the increasing level of socioeconomic inequalities in the three countries. Specifically, South Africa should prioritize the radical provision of social security and services to assist the poor. This could be achieved via an improved implementation of the present accelerated growth strategy to encourage public redistribution of resources and investment in critical infrastructures. On education, content-related coordination for education policy should be encouraged.

By designing programs that are capable of integrating learning methods and materials on socioeconomic sustainability into an agreed percentage of all classrooms curricula in all post-secondary schools in the three countries. This study acknowledges the fact that economic growth alone cannot solve the increasing income inequalities in Brazil, however, strategic radical policies should be formulated to demand better social standards from multinational companies operating in the country. Most importantly, Brazil must shift from the present dominance of the "industrialist paradigm", which tends to prioritize mainly the economic dimension of sustainability. There is also an urgent need to invigorate the present income transfer program, as well as, transparent land reform to increase the present level of disposable income needed by the poor and disadvantaged citizens in Brazil. Similar to the successful regional policies in Russia, Brazil may need to focus more on the creation of protected areas, indigenous people's settlements, as well as, special economic zones. In India, there is a need for an objective and transparent poverty alleviation program to reduce the increasing socioeconomic inequalities during the study period.

Unfortunately, due to the limited capacity of government to mobilize resources needed to accelerate the level of development, there is an urgent need to increase the level of cooperation with the organized private sector, via Public-Private Partnerships initiatives. To assist the poor and the increasing level of socioeconomic inequalities in South Africa, the Reconstruction and Development Programme (RDP) should be reinvigorated based on a long-term framework that is efficient and coherent in addressing targeted socioeconomic sustainability issues. There is also a need to prioritize the concept of nation-building, basic human needs, peace and security, and people-driven, growth processes in many Reconstruction and Development Programme (RDP) initiatives. Lastly, to improve the declining level of socioeconomic inequalities in Brazil, India and South Africa countries, the government will have to create a societal culture that is favorable to socioeconomic sustainability in each country. However, to achieve this noble objective, government institutions must work harmoniously with both civil society and business sectors. The creation of a societal culture that is favorable to socioeconomic sustainability can also be created through local level's promotion of best practices, increase in consumers' demand for sustainable clean services and products, transparent corporate reporting, as well as, required political will on the part of the government.

To provide the necessary funding, institutional support and other incentives. Despite the giant stride recorded by China and Russia in reducing socioeconomic inequalities over the study period, this study is unmindful of the necessity to improve the current challenges in the area of unemployment, uneven distribution of political and financial power, as well as, regional disparities, especially, in China. This is on the premise that it is only through even development strategies and viable interactions between the private sector, general public and government that can engender the formulation of transparent and equitable policies needed for the much desired sustainable economic growth in the BRICS. On the social dimension, the more advanced group in the bloc (China and Russia) could also emulate. Germany's "greying society" strategy of decoupling economic growth from socioeconomic inequalities and environmental pollution due to the probable increase in average age and decrease in size. In addition, China and Russia should also move further by integrating socioeconomic sustainability into their export/ trade policies. Most importantly, it is imperative for BRICS countries to understand that economic growth might not necessarily result in socioeconomic equality; rather, it may lead to an unprecedented increase in socio-economic inequalities, financial, institutional and market risks (Younsi \& Bechtini, 2018; Javeria et al., 2017).

Lastly, to improve the declining level of socioeconomic inequalities in Brazil, India and South Africa countries, government, will have to create a societal culture that is favorable to socioeconomic sustainability in each country. However, to achieve this noble objective, government institutions must work harmoniously with both civil society and business sectors. The creation of a societal culture that is favorable to socioeconomic 
sustainability can also be created through the local level's promotion of best practices, increase in consumers' demand for sustainable clean services and products, transparent corporate reporting. As well as, required political will on the part of the government to provide the necessary funding. Institutional support and other incentives. Despite the giant stride recorded by China and Russia in reducing socioeconomic inequalities over the study period, this study is unmindful of the necessity to improve the current challenges in the area of unemployment, uneven distribution of political and financial power, as well as, regional disparities, especially, in China. This is on the premise that it is only through even development strategies and viable interactions between the private sector.

The general public and government can engender the formulation of transparent and equitable policies needed for the much desired sustainable economic growth in the BRICS bloc. On the social dimension, the more advanced group in the bloc (China and Russia) could also emulate Germany's "greying society" strategy of decoupling economic growth from socioeconomic inequalities and environmental pollution due to the probable increase in average age and decrease in size. In addition, China and Russia should also move further by integrating socioeconomic sustainability into their export/ trade policies.

Managerial and Theoretical Contributions/ Implications: By investigating the short and long-run equilibrium relationships, as well as, estimating the joint effect among the socio-economic sustainability and economic growth variables have both managerial/ societal and theoretical implications/ contributions. First, the study provides a tool to understand the sustainability of BRICS and the achievement of its goals (Sesay et al. 2018; Agrawal, 2015; Awan, 2013). In line with a recent gap positioned in the literature and also to aid socio-economic sustainability and economic growth policy options, the main essence of establishing the relationships between socio-economic sustainability objectives and economic growth in the BRICS countries is to derive socio-economic criteria for economic growth to be sustainable (Hofkes, 2017; Hamilton, 2015; Fan \& Zheng, 2013; Spangenberg, 2004). Consequently, to the best of the researcher's knowledge, no study has investigated comprehensibly (along with multiple determinants) the sustainability of growth policy options within BRICS with an aim to proposing socioeconomic sustainability and growth policy options. Moreover, due to the strategic importance of BRICS countries in enhancing global economic growth and socioeconomic equality (sustainability), the paucity of studies on a trending issue, like the nexus between economic growth and socio-economic sustainability.

The bloc has been described as a major concern in literature (Younsi \& Bechtini, 2018). Consequently, the present study has been able to provide new empirical evidence concerning the aforementioned relationships. Additionally, in a deviation from previous studies that used a singular measure of socioeconomic sustainability, part of the novelty of this paper was the development of an aggregated composite index of socioeconomic inequality of a number of socioeconomic sustainability variables that have been used in the literature. Constructing the index comprising variables depicting various dimensions of socioeconomic sustainability was crucial as a single index might not give a strong measure of socioeconomic sustainability in the bloc, as well as, its capacity to correct past contradictory results in the literature. To the best of the researcher's knowledge, there has not been any study using an index whilst investigating sustainability in BRICS. In addition, many empirical works on socio-economic sustainability-economic growth nexus are often seen as confusing and contradictory, probably due to the use of singular measure and estimation techniques (Zha et al., 2019; Hofkes, 2017; Hamilton, 2015; Fan \& Zheng, 2013; Spangenberg, 2010).

Limitations and Suggestions for Further Studies: The first limitation, akin to most empirical studies on socio-economic inequality-economic growth relationships using cross-country data from most developing countries, is the probable presence of periods and country-specific omitted variables (Azevedo et al., 2018; Menon, 2017). Consequently, this study provides novel cross-validation of estimation techniques and robustness checks in response to many gaps in literature (Zha et al., 2019; Hofkes, 2017). Again, the output of this study will be beneficial to policymakers in the BRICS countries not only in estimating the achievement of many BRICS goals but also will serve as a "double-edged" tool for monitoring the BRICS' progress towards the attainment of the United Nations SDGs by the year 2030 (World Bank Group, 2018 Agrawal, 2015; Awan, 2013). This is usually due to poor data collection by relevant government agencies (World Bank Group, 2018; Pereira et al., 2018). Secondly, another "inevitable" flaw in many regression results is the constructs/specifications used to measure our variables (Menon, 2017). In addition, there may be problems 
of endogeneity (Anyanwu, 2012; Hailu, 2010). This is based on the premise that most of the explanatory variables may probably be jointly endogenous with socio-economic inequality (Agrawal, 2015). This may lead to biases from simultaneous or reverse causation, since each of the socio-economic inequality determinants may cause higher inequalities as opposed to the opposite (Younsi \& Bechtini, 2018). However, the use of the VECM approach is a deliberate attempt to address any potential endogeneity (El-Wassal, 2012).

Acknowledgments: This paper is an extract from my Ph.D. thesis at the University of KwaZulu-Natal, Durban, South Africa.

\section{References}

Adelakun, O. J. (2011). Human capital development and economic growth in Nigeria, European Journal of Business and Management, 3(9), 29-38.

Adelowokan, O. A. (2012). Growth effect of Education and Health Expenditure in Nigeria (1970-2010), African Journal of Scientific Research, 10(1), 510-528.

Agarwal, G. \& Khan, M. A. (2011). Impact of FDI on GDP: A comparative study of China and India, International Journal of Business and Management, 6(10), 71-79.

Agrawal, G. (2015). Foreign Direct Investment and Economic Growth in BRICS Economies: A Panel Data Analysis, Journal of Economics, Business and Management, 3(4), 421-424.

Akaike, H. (1974). A new look at statistical model identification. IEEE Transactions on Automatic Control, 19(1), 716-723.

Akinola G. W. \& Bokana K. G. (2017). Human Capital, Higher Education Enrolment and Economic Growth in the SSA Countries (Panel Model Approach), Journal of Economics and Behavioral Studies, 9(6), 215226.

Anyanwu, J. C. (2012). Why does foreign direct investment go where it goes? New evidence from African countries, Annals of Economics and Finance, 13(2), 433-470.

Aregbesola, A. R. (2014). Foreign direct investment and institutional adequacy: New Granger-causality evidence from African countries, South African Journal of Economic and Management Sciences, 17(5), 557-568.

Arellano, M. \& Bond, S. (1991). Some Tests of Specification for Panel Data: Monte Carlo Evidence and an Application to Employment Equations. The Review of Economic Studies, 58(2), 277-297.

Asteriou, D. \& Hall, S. G. (2007). Applied Econometrics: A Modern approach (revised ed.), NY: Palgrave Macmillan.

Awan, A. G. (2013). Diverging trends of human capital in BRICS countries, International Journal of Asian Social Science, 2(12), 2195-2219.

Awolusi, O. D. \& Mbonigaba, J. (2020). Socioeconomic sustainability and economic growth in BRICS: relationships and policy options, International Journal of Services, Economics and Management, 11(4), 390-429.

Kautsiro, F. \& Awolusi, O. D. (2020). Loyalty Programs for the Passenger Transportation Industry: A Study of Zimbabwean Companies, Journal of Education and Vocational Research, 11(1), 5-22.

Awolusi, O. D. (2019). Human Capital Development and Economic Growth in BRICS Countries: Controlling for Country Differences, Journal of Economics and Behavioral Studies, 11(4), 1-17.

Awosusi, 0. O. \& Awolusi, O. D. (2014). Technology Transfer, Foreign Direct Investment and Economic Growth in Nigeria, Africa Development, 39(2), 1- 20.

Azevedo, V. G., Sartori, S. \& Campos, L. M. (2018). CO2 emissions: A quantitative analysis among the BRICS nations, Renewable and Sustainable Energy Reviews, 81(1), 107-115.

Barro, R. J. (1990). Government spending in a simple model of endogenous growth, Journal of Political Economy, 98(5), S103-S125.

Bilgili, F., Koçak, E. \& Bulut, U. (2016). The dynamic impact of renewable energy consumption on CO2 emissions: A revisited Environmental Kuznets Curve approach, Renewable and Sustainable Energy Reviews, 54(1), 838-845.

Bindi, G. (2018). The resource curse hypothesis: an empirical investigation, a thesis submitted for the Master's Programme in Economics, School of Economics and Management, Lund University

Błazejowski, M., Kwiatkowski, J. \& Gazda, J. (2019). Sources of Economic Growth: A Global Perspective, Sustainability, 11(1), 275-288. 
Blundell, R. \& Bond, S. (1998). Initial conditions and moment restrictions in dynamic panel data models. Journal of Econometrics, 87(4), 115-143.

Breitenbach, M. C., Tipoy, C. K. \& Zerihun, M. F. (2017). Equilibrium Exchange Rates and Misalignments: The Case of Homogenous Emerging Countries, Economic Research Southern Africa (ERSA) working paper, 713.

Bryman, A. (2012). Social research methods (4thed.). New York, NY: Oxford University

Carnoy, M. (2006). Higher education and economic development: India, China, and the $21^{\text {st }}$ Century, working paper no. 297 presented at the Pan Asia Conference: Focus on Economic Challenges, Stanford Center for International Development May 31- June 3

Carnoy, M., Loyalka, P., Androushchak, G. \& Proudnikova, A. (2012). The economic returns to higher education in the BRIC countries and their implications for higher education expansion, basic research program working papers series: Education WP BRP 02/EDU/2012, the National Research University Higher School of Economics (HSE)

David E., Bloom, D. E. \& Canning, D. (2008). Population Health and Economic Growth, Working Paper no. 24: The International Bank for Reconstruction and Development / The World Bank On behalf of the Commission on Growth and Development, 1-27.

De Bruyn, S. M., Van den Bergh, J. C. \& Opschoor, J. B. (1998). Economic growth and emissions: reconsidering the empirical basis of environmental Kuznets curves, Ecological Economics, 25(1), 161-175.

De Mello, L. R. (1996). Foreign direct investment, international knowledge transfers, endogenous growth: Time series evidence. Department of Economics, University of Kent, 234-240.

Diesendorf, M. (2000). Sustainability and sustainable development, in Dunphy, D, Benveniste, J, Griffiths, A and Sutton, P (eds) Sustainability: The corporate challenge of the 21st century, Sydney: Allen \& Unwin, chap, 2(1), 19-37.

Eggoh, J., Houeninvo, H. \& Sossou, G. (2015). Education, Health and Economic Growth in African Countries, Journal of Economic Development, 40(1), 93-111.

El-Wassal, K. A. (2012). Foreign direct investment and economic growth in Arab Countries (1970-2008): An inquiry into determinants of growth benefits, Journal of Economic Development, 37(4), 79-100.

Fan C. \& Zheng, X. (2013). An empirical study of the environmental Kuznets curve in Sichuan Province, China, Environmental Pollution, 2(3), 107-125.

Fedderke, J. \& Romm, A. T. (2005). Growth impact and determinants of foreign direct investment into South Africa, 1956-2003. Economic Modelling, 23(2), 738-760.

Felipe, J. (1997). Total factor productivity growth in East Asia: A critical survey, Economics and Development Research Center Report Series No. 65, Asian Development Bank, 233-235.

Frenkel, M., Funke, K. \& Stadtmann, G. (2004). A panel analysis of bilateral FDI flows to emerging economies, Economic System, 28(3), 281-300.

Goldman Sachs. (2001). Building better global economic BRICs. Accessed from http://www.goldmansachs.com/our-thinking/topics/brics/brics-reports-pdfs/build-better-brics.pdf as of 18 th December 2014

Grossman, G. M. \& Helpman, E. (1990). Trade, innovation, and growth, The American Economic Review, 80(2), 86-91.

Gur, B. (2015). An Analysis of Unemployment Determinants in BRIC Countries, International Journal of Business and Social Science, 6(1), 192-198.

Hailu, Z. A. (2010). Demand-side factors affecting the inflow of foreign direct investment to African Countries: Does the capital market matter? International Journal of Business and Management, 5(5), 104-116.

Hamilton, K. (2015). Sustainable development, the Hartwick rule and optimal growth, Environmental and Resource Economics, 21(1), 393-411.

Hayek, F. A. (1960). The constitution of liberty. Routledge, London

Hayek, F. A. (1973). Law, legislation and liberty, vol 1. Routledge, London

Hochestler, K. (2014). Infrastructure and sustainable development goals in the BRICS-Led New development bank, Policy Brief No. 46, Centre for International Governance Innovation: NY

Hofkes, M. W. (2017). Modeling sustainable development: an economy-ecology integrated model, Economic modeling, 13(1), 333-353.

Hussin, M. Y. M., Muhammad, F., Abu, M. F. \& Awang, S. A. (2012). Macroeconomic Variables and Malaysian Islamic Stock Market: A Time Series Analysis, Journal of Business Studies Quarterly, 3(4), 1-13. 
ISSA. (2017). BRICS countries: Sustainability challenges for social security systems, International Social Security Association: NY

Javeria, M., Ashok, M. \& Vishal, S. (2017). C02 Emissions, Energy Consumption and Economic growth in BRICS: An empirical analysis, IOSR Journal of humanities and social science, 22(2), 53-58.

Jamel, L. \& Maktouf, S. (2017). The nexus between economic growth, financial development, trade openness, and CO2 emissions in European countries, Cogent Economics \& Finance, 5(1), 134-145.

Johansen, S. \& Juselius, K. (1990). Maximum likelihood estimation and inference on Cointegration - with application to the demand for money, Oxford Bulletin of Economics and Statistics, 52(2), 169-210.

Kwiatkowski, D., Phillips, P. C. B., Schmidt, P. \& Shin, Y. [KPSS] (1992). Testing the Null Hypothesis of Stationary against the Alternative of a Unit Root', Journal of Econometrics, 54(1), 159-178.

Lee, H. H. \& Tan, H. B. (2006). Technology transfer, FDI and economic growth in the ASEAN Region, Journal of the Asia Pacific Economy, 11(4), 394-410.

Licumba, E. A., Dzator, J. \& Zhang, X. (2016). Health and economic growth: are there gendered effects? Evidence from selected southern Africa development community Region, The Journal of Developing Areas, 50(5), 215-227.

Mahe, S. A. (2005). Is globalization capable of raising living standards, through international trade in Nigeria? Downloaded from http://www.hollerafrica.com/showArticle.php?artId=143\&catId=2 on 21 July 2008.

Mankiw, N. G., Romer, D. \& Weil, D. N. (1992). Contribution to the empirics of economic growth, The Quarterly Journal of Economics, 107(2), 407-437.

Menon, A. A. (2017). Performance of Economic Growth in BRICS Countries, International Journal of Informative \& Futuristic Research, 4(5), 6200-6203.

Mosteanu, N. R. (2019). Regional development and economic growth approach in Europe and GCC countries, ECOFORUM, 8(2-19), 1-12.

Nkoro, E. \& Uko, A. K. (2016). Autoregressive Distributed Lag (ARDL) cointegration technique: application and interpretation, Journal of Statistical and Econometric Methods, 5(4), 63-91.

North, D. C. (1971). Institutional change and economic growth, Journal of Economic History, 31(1), 118-125.

North, D. C. (1989). Institutions and economic growth: a historical introduction, World Development, 17(9), 1319-1332.

North, D. C. (2005) Understanding the process of economic change. Princeton University Press.

Princeton Odunlami, S. A. \& Awolusi, O. D. (2015). Multinational Corporation and economic development in Nigeria, American Journal of Environmental Policy and Management, 1(2), 16-24.

Ogasawara, K. (2018). Health and education during industrialization: Evidence from early twentieth-century Japan, International Journal of Educational Development, 61(1), 40-54.

Oladipo, O. S. (2008). Foreign direct investment flow: Determinants and growth effects in a small open economy, Proceedings of the Northeast Business \& Economics Association, Northeast Business \& Economics Association 35th Annual Conference, Long Island, New York, 6-8 November.

Omer, A. M. (2008). Energy, Environment and Sustainable Development, Renewable and Sustainable Energy Reviews, 12(9), 2265-2300.

Ozturk, I. (2007). Foreign direct investment-growth nexus: A review of the recent literature, International Journal of Applied Econometrics and Quantitative Studies, 4(2), 79-98.

Pelinescu, E. (2015). The impact of human capital on economic growth, Procedia Economics and Finance, 22(1), 184-190.

Pereira, C. A., Ferraz, J. F., Araujo, E. \& Machado-Taylor, M. (2018). The Brazilian higher education evaluation model: "SINAES" sui generis, International Journal of Educational Development, 61(3), 128-137.

Pistorius, C. (2004).The competitiveness and innovation, Elektron, 2(3), 234-245.

Polasky, S., Kling, C. L., Levin, S. A., Carpenter, S. R., Daily, G. C., Ehrlich, P. R., Heal, G. M. \& Lubchenco, J. (2019). "Role of economics in analyzing the environment and sustainable development", Colloquium Introduction, 116(12), 5233-5238.

Riley, G. (2012). Economic growth - the role of human \& social capital, competition \& innovation. Accessed from http://www.tutor2u.net/economics/revisionnotes/a2-macro-economic-growth-capital.html, 16 April 2014.

RSA. (2013). South Africa's positions in BRICS, Quarterly Bulletin- January to March 2013. Gauteng Provincial Treasury, Republic of South Africa. 
Sesay, B., Yulin, Z. \& Wang, F. (2018). Does the national innovation system spur economic growth in Brazil, Russia, India, China and South Africa economies? Evidence from panel data, South African Journal of Economic and Management Sciences, 21(1), 16-47.

Strittmatter, A. \& Sunde, U. (2011). Health and Economic Development: Evidence from the Introduction of Public Health Care, Discussion Paper No. 5901: The Institute for the Study of Labor (IZA), 1-53.

Spangenberg, J. H. (2004). Reconciling Sustainability and growth: Criteria, Indicators, Policies, Sustainable Development, 12(1), 74-86.

Temple, J. (1999). A positive effect of human capital on growth, Economics Letters, 65(3), 131-134.

United Nations. (2013). Sustainable Development Challenges, World Economic and Social Survey, 2013; World Economic and Social Survey, The Department of Economic and Social Affairs of the United Nations, United Nations publication: NewYork

UNCSD. (2012). The future we want, the outcome document of the 2012 United Nations Conference on Sustainable Development, United Nations: Geneva

Wilhelms, S. K. S. (1998). Foreign Direct Investment and its determinants in emerging economies, African Economic Policy Paper Discussion Paper Number 9, July

World Bank Group. (2018). Global Economic prospects: Broad-Based Upturn, but for How Long? A World Bank Group flagship report: NW, Washington

Younsi, M. \& Bechtini, M. (2018). Economic Growth, Financial Development and Income Inequality in BRICS Countries: Evidence from Panel Granger Causality Tests, Munich Personal RePEc Archive (MPRA) Paper No. 85249

Zha, J., Tan, T., Yuan, W., Yang, X. \& Zhu, Y. (2019). Decomposition analysis of tourism C02 emissions for sustainable development: A case study of China, Sustainable Development, 10(1), 1-18.

\section{Appendix}

\begin{tabular}{|c|c|c|c|c|c|c|c|c|c|c|c|}
\hline \multicolumn{4}{|l|}{ Brazil } & \multicolumn{5}{|c|}{ Eigenvalues $($ Sum $=5$, Average $=1$ ) } & \multicolumn{3}{|c|}{ Eigenvectors (loadings } \\
\hline Number & Value & Difference & Proportion & $\begin{array}{l}\text { Cumulative } \\
\text { value }\end{array}$ & $\begin{array}{l}\text { Cumulative } \\
\text { proportion }\end{array}$ & Variable & PC 1 & PC 2 & PC3 & PC4 & PC5 \\
\hline 1 & 2.9046 & 1.7518 & 0.5813 & 2.90646 & 0.5813 & GCII & 0.7845 & -0.0343 & -0.4664 & -0.8636 & 0.0637 \\
\hline 2 & 1.1546 & 0.56031 & 0.2309 & 4.06112 & 0.8122 & AI & 0.7825 & 0.0452 & 0.5665 & -0.6263 & 0.0785 \\
\hline 3 & 0.5945 & 0.3956 & 0.1189 & 4.65547 & 0.9311 & RFMLF & 0.3966 & 0.7474 & 0.5646 & 0.0375 & 0.0335 \\
\hline 4 & 0.2885 & 0.23297 & 0.0578 & 4.94422 & 0.9889 & UNEMP & 0.4143 & 0.6577 & 0.6544 & 0.0475 & 0.0485 \\
\hline 5 & 0.0558 & ------- & 0.0111 & 5.00000 & 1.0000 & RPOP & 0.3210 & -0.7751 & 0.6070 & 0.0777 & 0.0877 \\
\hline \multicolumn{12}{|l|}{ Russia } \\
\hline 1 & 2.8674 & 1.52187 & 0.5734 & 2.86754 & 0.5734 & GCII & 0.6004 & -0.0051 & -0.4634 & 0.6529 & 0.6569 \\
\hline 2 & 1.3457 & 1.05229 & 0.2691 & 4.21321 & 0.8425 & AI & 0.6019 & 0.0731 & -0.2708 & -0.7439 & -0.7689 \\
\hline 3 & 0.2938 & 0.00995 & 0.0587 & 4.50659 & 0.9012 & RFMLF & 0.2945 & 0.7671 & 0.5318 & 0.1081 & 0.1781 \\
\hline 4 & 0.2833 & 0.07345 & 0.0566 & 4.79002 & 0.9578 & UNEMP & 0.3243 & 0.8564 & 0.6567 & 0.2653 & 0.2983 \\
\hline 5 & 0.2098 & ------- & 0.0422 & 5.00000 & 1.0000 & RPOP & 0.4366 & -0.7168 & 0.6559 & 0.0586 & 0.0566 \\
\hline \multicolumn{12}{|l|}{ India } \\
\hline 1 & 3.0215 & 1.99689 & 0.6042 & 3.02145 & 0.6042 & GCII & 0.5835 & -0.0108 & -0.6143 & 0.5303 & 0.5563 \\
\hline 2 & 1.0246 & 0.56809 & 0.2049 & 4.04601 & 0.8091 & AI & 0.5862 & 0.0370 & -0.1331 & -0.7983 & -0.7673 \\
\hline 3 & 0.4567 & 0.20462 & 0.0913 & 4.50248 & 0.9004 & RFMLF & 0.3730 & 0.7514 & 0.5188 & 0.2035 & 0.2565 \\
\hline 4 & 0.2515 & 0.00618 & 0.0504 & 4.75433 & 0.9504 & UNEMP & 0.3905 & 0.8664 & 0.6785 & 0.3542 & 0.3785 \\
\hline
\end{tabular}




\begin{tabular}{|c|c|c|c|c|c|c|c|c|c|c|c|}
\hline \multicolumn{12}{|c|}{$\begin{array}{l}\text { Journal of Economics and Behavioral Studies (ISSN: 2220-6140) } \\
\qquad \text { Vol. 13, No. 3, pp. 1-23, June } 2021\end{array}$} \\
\hline 5 & 0.2457 & --- & 0.0492 & 5.00000 & 1.0000 & RPOP & 0.4194 & -0.6505 & 0.5792 & 0.1963 & 0.1233 \\
\hline \multicolumn{12}{|c|}{ China } \\
\hline 1 & 3.2347 & 2.28894 & 0.6469 & 3.23457 & 0.6469 & GCII & 0.5493 & -0.0423 & -0.5873 & -0.5914 & -0.5764 \\
\hline 2 & 0.9453 & 0.58020 & 0.1891 & 4.1802 & 0.8360 & AI & 0.5465 & -0.2625 & -0.2499 & 0.7706 & 0.7786 \\
\hline 3 & 0.3653 & 0.08907 & 0.0731 & 4.54563 & 0.9091 & RFMLF & 0.3593 & 0.9672 & 0.2072 & 0.0623 & 0.0873 \\
\hline 4 & 0.2766 & 0.09835 & 0.0553 & 4.82199 & 0.9644 & UNEMP & 0.4125 & 0.9742 & 0.3557 & 0.1234 & 0.0763 \\
\hline 5 & 0.1781 & ------- & 0.0356 & 5.00000 & 1.0000 & RPOP & 0.5199 & -0.3697 & 0.7414 & -0.2275 & -0.2875 \\
\hline 1 & 3.5464 & 2.28875 & 0.7093 & 3.54654 & 0.7093 & GCII & 0.5653 & -0.0850 & -0.7854 & -0.2457 & -0.2687 \\
\hline 2 & 1.2885 & 1.21230 & 0.2578 & 4.83529 & 0.9671 & $\mathrm{AI}$ & 0.5681 & -0.1347 & 0.5922 & -0.5615 & -0.5655 \\
\hline 3 & 0.07645 & 0.02002 & 0.0153 & 4.91174 & 0.9824 & RFMLF & 0.5721 & -0.1281 & 0.1800 & 0.7916 & 0.7566 \\
\hline 4 & 0.0563 & 0.02460 & 0.0113 & 4.96817 & 0.9937 & UNEMP & 0.6753 & 0.1334 & 0.2654 & 0.8343 & -0.8784 \\
\hline 5 & 0.03183 & --.---.- & 0.0063 & 5.00000 & 1.0000 & RPOP & 0.17250 & 0.92454 & 0.02487 & 0.01725 & 0.02355 \\
\hline
\end{tabular}

Note: GCII= Gini coefficient-income inequality; AI= Atkinson index; RFMLF= Ratio of female to male labor force participation rate; UNEMP= Unemployment, total; RPOP= Refugee population by country or territory of origin.

Appendix 2B(i): ADF-Augmented Dickey-Fuller Test Results

\begin{tabular}{|c|c|c|c|c|}
\hline Variables & $\begin{array}{l}\text { Level } \\
\text { Constant } \\
\text { without Trend }\end{array}$ & $\begin{array}{l}\text { Constant } \\
\text { with Trend }\end{array}$ & $\begin{array}{l}\text { First Difference } \\
\text { Constant } \\
\text { without Trend }\end{array}$ & $\begin{array}{l}\text { Constant } \\
\text { with Trend }\end{array}$ \\
\hline \multicolumn{5}{|l|}{ Brazil } \\
\hline$\overline{\text { HEALTH }}$ & -2.122692 & -2.245592 & $-5.190527^{*}$ & $-5.110880 *$ \\
\hline EDU & 4.333768 & 0.697322 & $-3.199933^{* *}$ & $-4.325263^{*}$ \\
\hline FIN & -1.440994 & -2.572330 & $-7.200976^{*}$ & $-7.096229^{*}$ \\
\hline INST & 2.932019 & -0.662914 & $-4.238610^{*}$ & $-5.174591 *$ \\
\hline GDP & 1.843983 & -0.778404 & $-4.414912^{*}$ & $-4.963164^{*}$ \\
\hline TO & 1.492769 & -1.215579 & $-4.902542 *$ & $-5.428332^{*}$ \\
\hline $\mathrm{CO} 2$ & 3.856019 & -0.665514 & $-3.567710^{*}$ & $-6.434591^{*}$ \\
\hline EC & 2.565383 & -0.234404 & $-4.543612^{*}$ & $-4.543464^{*}$ \\
\hline INQ & 2.665349 & -1.653449 & $-4.566462^{*}$ & $-5.354632 *$ \\
\hline \multicolumn{5}{|l|}{ Russia } \\
\hline HEALTH & -1.144648 & -2.945136 & $-4.788712^{*}$ & $-4.709925^{*}$ \\
\hline EDU & 3.714916 & 0.791333 & -1.521439 & $-5.965081 *$ \\
\hline FIN & 1.021374 & 1.505314 & 0.607969 & $-4.552479 *$ \\
\hline INST & 2.720547 & -1.191821 & $-3.302965^{* *}$ & $-3.907973^{* *}$ \\
\hline GDP & 1.908789 & -0.216484 & $-3.788318^{*}$ & $-4.137955^{* *}$ \\
\hline TO & 2.645126 & -2.572635 & $-4.555648^{*}$ & $-4.852589 *$ \\
\hline $\mathrm{CO} 2$ & 2.456787 & -1.453521 & $-3.455565^{* *}$ & $-3.455343^{* *}$ \\
\hline EC & 1.764349 & -0.345584 & $-3.453348^{*}$ & $-4.344455^{* *}$ \\
\hline INQ & 3.645556 & -2.542435 & $-4.334458^{*}$ & $-4.564669^{*}$ \\
\hline \multicolumn{5}{|l|}{ India } \\
\hline HEALTH & 2.124335 & -0.309808 & $-3.145541^{* *}$ & $-3.361598^{* * *}$ \\
\hline EDU & 2.514984 & 1.442281 & $-3.301828^{* *}$ & $-3.687529 * *$ \\
\hline FIN & 2.993062 & -0.704361 & $-5.639046^{*}$ & $-6.088482^{*}$ \\
\hline INST & 1.172443 & -3.352558 & $-6.807686^{*}$ & $-6.722904^{*}$ \\
\hline GDP & -1.282022 & -0.737150 & $-4.567816^{*}$ & $-4.563187^{*}$ \\
\hline
\end{tabular}




\begin{tabular}{|c|c|c|c|c|}
\hline \multicolumn{5}{|c|}{$\begin{array}{l}\text { Journal of Economics and Behavioral Studies (ISSN: 2220-6140) } \\
\text { Vol. 13, No. 3, pp. 1-23, June 2021 } \\
\end{array}$} \\
\hline TO & 1.268557 & -0.224709 & $-5.805208^{*}$ & $-6.405380^{*}$ \\
\hline $\mathrm{CO} 2$ & 2.665547 & -1.566421 & $-3.355665^{* *}$ & $-3.554563^{* *}$ \\
\hline EC & 1.564389 & -0.256684 & $-3.756418^{*}$ & $-4.455355^{* *}$ \\
\hline INQ & 0.567746 & -2.572667 & $-4.545668^{*}$ & $-4.564689 *$ \\
\hline \multicolumn{5}{|l|}{ China } \\
\hline HEALTH & -1.176535 & 1.287363 & $-4.3838827^{*}$ & $-2.222880^{*}$ \\
\hline EDU & 3.275633 & 0.838877 & $-3.8376673^{* *}$ & $-4.376747^{*}$ \\
\hline FIN & -2.986794 & -2.848493 & $-7.238377^{*}$ & $-4.383773^{*}$ \\
\hline INST & 1.345519 & -2.774647 & $-3.238610^{*}$ & $-3.1444441^{*}$ \\
\hline GDP & 1.324583 & -1.884474 & $-3.414912^{*}$ & $-4.943334^{*}$ \\
\hline TO & 1.238569 & 1.487436 & $-2.302542^{*}$ & $-3.467462^{*}$ \\
\hline $\mathrm{CO} 2$ & 2.756667 & -1.191821 & $-3.302965^{* *}$ & $-3.907973^{* *}$ \\
\hline EC & 1.908789 & -0.216484 & $-3.788318^{*}$ & $-4.137955^{* *}$ \\
\hline INQ & 0.645654 & -2.572635 & $-4.555648^{*}$ & $-4.852589^{*}$ \\
\hline \multicolumn{5}{|c|}{ South Africa } \\
\hline HEALTH & 1.8878748 & 1.9773736 & $3.3737412^{*}$ & $-3.456925^{*}$ \\
\hline EDU & 3.494894 & 0.8984783 & $-1.374649^{* *}$ & $-5.687771^{*}$ \\
\hline FIN & 2.099894 & 1.2833838 & $0.333949 *$ & $-3.533459^{*}$ \\
\hline INST & 2.298934 & -1.239399 & $-3.302934^{* *}$ & $-4.907333^{* *}$ \\
\hline GDP & 1.988473 & -0.393948 & $-3.788345^{*}$ & $-5.333955^{* *}$ \\
\hline TO & 1.998887 & -2.388489 & $-4.522299 * *$ & $-5.333589 *$ \\
\hline $\mathrm{CO} 2$ & 2.756447 & -1.134521 & $-3.3345965^{* *}$ & $-3.675473^{* *}$ \\
\hline EC & 1.678789 & -0.245684 & $-3.564318^{*}$ & $-4.135565^{* *}$ \\
\hline INQ & 0.645675 & -2.545635 & $-4.557648^{*}$ & $-4.453689 *$ \\
\hline
\end{tabular}

Note: ${ }^{*}, * *$ and ${ }^{* * *}$ implies $1 \%, 5 \%$ and $10 \%$ levels of significance, respectively.

Appendix 2B(ii): Phillips-Perron (PP) Test Results

\begin{tabular}{lllll}
\hline Variables & $\begin{array}{l}\text { Level } \\
\text { Constant } \\
\text { without Trend }\end{array}$ & $\begin{array}{l}\text { Constant } \\
\text { with Trend }\end{array}$ & $\begin{array}{l}\text { First Difference } \\
\text { Constant } \\
\text { without Trend }\end{array}$ & $\begin{array}{l}\text { Constant } \\
\text { with Trend }\end{array}$ \\
\hline Brazil & & & & \\
HEALTH & -1.201432 & -2.245592 & $-5.144889^{*}$ & $-5.057306^{*}$ \\
EDU & 3.924001 & 0.725865 & $-3.135526^{* *}$ & $-4.07412^{* *}$ \\
FIN & -1.275166 & -2.664606 & $-7.202274^{*}$ & $-7.096805^{*}$ \\
INST & 2.822786 & -0.738637 & $-4.232497^{*}$ & $-5.174591^{*}$ \\
GDP & 1.976495 & -0.852797 & $-4.400720^{*}$ & $-4.860987^{*}$ \\
TO & 1.571491 & -1.210226 & $-4.900783^{*}$ & $-5.407357^{*}$ \\
CO2 & 2.345566 & -0.756437 & $-4.435697^{*}$ & $-5.567791^{*}$ \\
EC & 1.453675 & -0.845367 & $-4.445320^{*}$ & $-4.845687^{*}$ \\
INQ & 1.234561 & -1.342576 & $-4.923483^{*}$ & $-5.476557^{*}$ \\
& & & & \\
Russia & & & & \\
HEALTH & & -1.745726 & $-2.89435^{* * *}$ & -2.801947 \\
EDU & -1.120844 & 1.024137 & $-5.627780^{*}$ & $-6.489557^{*}$ \\
FIN & 3.588824 & -1.832620 & $-6.052339^{*}$ & $-7.737240^{*}$ \\
INST & 1.384242 & -0.929186 & $-3.302965^{* *}$ & $-3.89165^{* *}$ \\
GDP & 2.266872 & -0.076366 & $-3.954526^{*}$ & $-4.380714^{*}$ \\
TO & 1.908789 & -1.470557 & $-3.455271^{* *}$ & $-4.975931^{*}$ \\
CO2 & 1.175334 & -0.745337 & $-4.345497^{*}$ & $-5.176591^{*}$ \\
EC & 2.345686 & -0.844397 & $-4.405630^{*}$ & $-4.867887^{*}$ \\
INQ & 1.564695 & -1.345226 & $-4.906743^{*}$ & $-5.473975^{*}$ \\
& 1.452491 & & & \\
\hline & & & &
\end{tabular}




\begin{tabular}{|c|c|c|c|c|}
\hline \multicolumn{5}{|l|}{ India } \\
\hline HEALTH & 0.439370 & -0.148130 & $-2.65569 * * *$ & -2.604309 \\
\hline EDU & 2.320468 & 0.972072 & $-3.30182^{* *}$ & $-3.74274^{* *}$ \\
\hline FIN & 1.763926 & 0.704361 & $-5.641124^{*}$ & $-6.086636^{*}$ \\
\hline INST & 0.018424 & -2.356968 & $-6.769487^{*}$ & $-6.689742^{*}$ \\
\hline GDP & -0.809650 & -1.275888 & $-4.613034^{*}$ & $-4.607808^{*}$ \\
\hline TO & 1.599318 & -0.295587 & $-5.888616^{*}$ & $-6.383675^{*}$ \\
\hline $\mathrm{CO} 2$ & 2.452786 & -0.453637 & $-4.256397 *$ & $-5.156491 *$ \\
\hline $\mathrm{EC}$ & 1.453495 & -0.453797 & $-4.453720^{*}$ & $-4.845387 *$ \\
\hline INQ & 1.556491 & -1.554926 & $-4.567783^{*}$ & $-5.445357^{*}$ \\
\hline \multicolumn{5}{|l|}{ China } \\
\hline HEALTH & -1.736632 & 1.245592 & $-4.345889 * *$ & $-3.789306^{*}$ \\
\hline EDU & 2.787301 & 0.725865 & $-4.134526^{*}$ & $-4.789412^{* *}$ \\
\hline FIN & 1.776866 & 2.978606 & $-5.778274^{* *}$ & $-5.45505^{*}$ \\
\hline INST & 2.444486 & -0.738637 & $-3.666497 *$ & $-5.986791 *$ \\
\hline GDP & 1.097695 & -1.374797 & $-4.345720^{*}$ & $-4.845787^{*}$ \\
\hline TO & 2.354671 & -1.447226 & $-3.456783^{*}$ & $-4.448957^{*}$ \\
\hline $\mathrm{CO} 2$ & 2.456886 & -0.453537 & $-4.567897 *$ & $-5.123491 *$ \\
\hline EC & 1.965495 & -0.564997 & $-4.543720^{*}$ & $-4.345987 *$ \\
\hline INQ & 1.534591 & -1.453826 & $-4.645783^{*}$ & $-5.345357^{*}$ \\
\hline \multicolumn{5}{|c|}{ South Africa } \\
\hline HEALTH & 1.475844 & 1.456726 & $-3.894354^{* *}$ & -3.801947 \\
\hline EDU & 2.846824 & 1.566137 & $-4.634559 * * *$ & $-6.489557^{*}$ \\
\hline FIN & -1.384672 & -1.433620 & $-6.056789 *$ & $-2.737240 *$ \\
\hline INST & 2.264645 & -0.929445 & $-4.302365^{*}$ & $-3.89165^{* *}$ \\
\hline GDP & 2.908748 & -0.878774 & $-2.444526^{*}$ & $-3.380714^{*}$ \\
\hline TO & 1.364734 & -1.577373 & $-2.345271^{* *}$ & $-3.975931^{*}$ \\
\hline $\mathrm{CO} 2$ & 2.867586 & -0.345637 & $-4.567497^{*}$ & $-5.156491^{*}$ \\
\hline $\mathrm{EC}$ & 1.976897 & -0.657797 & $-4.454630^{*}$ & $-4.856487^{*}$ \\
\hline INQ & 1.576754 & -1.256426 & $-4.678983 *$ & $-5.456757 *$ \\
\hline
\end{tabular}

Note: ${ }^{*},{ }^{* *}$ and ${ }^{* * *}$ implies $1 \%, 5 \%$ and $10 \%$ levels of significance, respectively.

Appendix 2B (iii): Kwiatkowski-Phillips-Schmidt-Shin (KPSS) Test Results

\begin{tabular}{llcll}
\hline Variables & $\begin{array}{l}\text { Level } \\
\text { Constant } \\
\text { without Trend }\end{array}$ & $\begin{array}{l}\text { Constant } \\
\text { with Trend }\end{array}$ & $\begin{array}{l}\text { First Difference } \\
\text { Constant } \\
\text { without Trend }\end{array}$ & $\begin{array}{l}\text { Constant } \\
\text { with Trend }\end{array}$ \\
\hline Brazil & & & & \\
HEALTH & $0.569937^{* *}$ & 0.075514 & 0.062453 & 0.060117 \\
EDU & $0.690808^{* *}$ & $0.213009^{* *}$ & 0.192955 & 0.103680 \\
FIN & $0.766940^{*}$ & $0.208883^{* *}$ & 0.263632 & $0.169095^{* *}$ \\
INST & $0.710045^{* *}$ & $0.183612^{* *}$ & 0.435652 & 0.063018 \\
GDP & $0.699347^{* *}$ & $0.165347^{* *}$ & 0.119382 & 0.098581 \\
TO & $0.683356^{* *}$ & $0.155069^{* *}$ & 0.266995 & 0.091497 \\
CO2 & $0.5674045^{* *}$ & $0.185672^{* *}$ & 0.453652 & 0.076518 \\
EC & $0.5678347^{* *}$ & $0.156437^{* *}$ & 0.234582 & 0.045381 \\
INQ & $0.7654356^{* *}$ & $0.155649^{* *}$ & 0.265495 & 0.076597 \\
& & & & \\
Russia & & & & \\
HEALTH & & $0.14051^{* * *}$ & 0.293300 & $0.158950^{* *}$ \\
EDU & & $0.14550^{* * *}$ & 0.195006 & $0.178243^{* *}$ \\
FIN & $0.325089^{* *}$ & $0.13006^{* * *}$ & 0.315861 & 0.117715 \\
INST & $0.507892^{* *}$ & & & 0.105210 \\
\hline
\end{tabular}




\begin{tabular}{|c|c|c|c|c|}
\hline \multicolumn{5}{|c|}{$\begin{array}{l}\text { Journal of Economics and Behavioral Studies (ISSN: 2220-6140) } \\
\text { Vol. 13, No. 3, pp. 1-23, June 2021 }\end{array}$} \\
\hline GDP & $0.414510^{* *}$ & 0.112198 & 0.173065 & 0.133714 \\
\hline TO & $0.648086^{* *}$ & $0.14437^{* * *}$ & 0.321293 & 0.109837 \\
\hline $\mathrm{CO} 2$ & $0.564045^{* *}$ & 0.072152 & 0.345652 & 0.078618 \\
\hline $\mathrm{EC}$ & $0.453347^{* *}$ & 0.115674 & 0.234582 & 0.087681 \\
\hline INQ & $0.678356^{* *}$ & $0.145377^{* * *}$ & 0.456995 & 0.076897 \\
\hline \multicolumn{5}{|l|}{ India } \\
\hline$\overline{\text { HEALTH }}$ & $0.587939^{* *}$ & 0.234516 & 0.127752 & 0.048479 \\
\hline EDU & $0.689880^{* *}$ & $0.345127^{*}$ & 0.267364 & 0.048745 \\
\hline FIN & $0.540484^{* *}$ & $0.374647^{*}$ & 0.064848 & 0.049589 \\
\hline INST & $0.714983^{* *}$ & $0.364731^{* *}$ & 0.164947 & 0.054477 \\
\hline GDP & $0.8498370^{* *}$ & $0.4784886^{* *}$ & 0.113487 & 0.061457 \\
\hline TO & $0.0984806^{* *}$ & $0.1494944^{* *}$ & 0.455836 & 0.057547 \\
\hline $\mathrm{CO} 2$ & $0.675045^{* *}$ & 0.453652 & 0.543652 & 0.087618 \\
\hline EC & $0.567347^{* *}$ & 0.145398 & 0.567382 & 0.089781 \\
\hline INQ & $0.456356^{* *}$ & $0.564737^{* * *}$ & 0.345995 & 0.098597 \\
\hline \multicolumn{5}{|l|}{ China(C) } \\
\hline HEALTH & $0.3454937^{* *}$ & 0.485859 & 0.344453 & 0.160117 \\
\hline EDU & $0.5564808^{* *}$ & $0.254858^{* *}$ & 0.846955 & 0.149980 \\
\hline FIN & $0.3455440 *$ & $0.258595^{* *}$ & 0.646532 & 0.169044 \\
\hline INST & $0.7347665^{* *}$ & $0.148585^{* *}$ & 0.847452 & 0.063456 \\
\hline GDP & $0.6099585^{* *}$ & $0.222284 * *$ & 0.147482 & 0.094555 \\
\hline T0 & $0.6846747^{*}$ & $0.484949 * *$ & 0.276487 & 0.093455 \\
\hline $\mathrm{CO} 2$ & $0.564045^{* *}$ & 0.564152 & 0.564652 & 0.089718 \\
\hline EC & $0.567347^{* *}$ & 0.564198 & 0.546382 & 0.097861 \\
\hline INQ & $0.567356^{* *}$ & $0.56437^{* * *}$ & 0.345995 & 0.099987 \\
\hline \multicolumn{5}{|c|}{ South Africa } \\
\hline HEALTH & $0.8747748^{* *}$ & $0.140457^{* * *}$ & 0.294674 & 0.158954 \\
\hline EDU & 0.5489333* & $0.1458595^{* *}$ & 0.195006 & $0.178553^{* *}$ \\
\hline FIN & $0.7454857^{*}$ & $0.135586^{* * *}$ & 0.347484 & 0.117456 \\
\hline INST & $0.5958474^{* *}$ & $0.075859^{*}$ & 0.348496 & 0.557810 \\
\hline GDP & $0.4147585^{* *}$ & 0.154575 & 0.149847 & 0.157614 \\
\hline TO & $0.6458990^{* *}$ & $0.194859^{* *}$ & 0.347567 & 0.475847 \\
\hline CO2 & $0.678045^{* *}$ & 0.456152 & 0.567652 & 0.065678 \\
\hline EC & $0.789347^{* *}$ & 0.453198 & 0.564382 & 0.097681 \\
\hline INQ & $0.345356^{* *}$ & $0.45637^{* * *}$ & 0.345995 & 0.098997 \\
\hline
\end{tabular}

Note: $*, * *$ and ${ }^{* * *}$ implies $1 \%, 5 \%$ and $10 \%$ levels of significance, respectively.

\begin{tabular}{|c|c|c|c|c|c|c|c|}
\hline \multicolumn{2}{|c|}{ Co-integration Order } & \multicolumn{3}{|c|}{ Trace } & \multicolumn{3}{|c|}{ Maximum Eigenvalue } \\
\hline Null & Alternative & Statistics & C. V. & vel) & & C.V (0.05 leve & \\
\hline \multicolumn{8}{|c|}{ Brazil Variables (INQ, HEALTH, EDU, FIN, INST, GDP, TO, CO2, EC) $(P=2)$} \\
\hline $\mathrm{r}=0.0$ & $r \geq 1.0$ & & $.5710^{*}$ & 95. & 366 & $65.30743^{*}$ & 40.07757 \\
\hline$r \leq 1.0$ & $r \geq 2.0$ & & $.2635^{*}$ & 69. & 889 & $49.73640^{*}$ & 33.87687 \\
\hline $\mathrm{r} \leq 2.0$ & $r \geq 3.0$ & & 5271* & 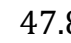 & 613 & $30.32430^{*}$ & 27.58434 \\
\hline$r \leq 3.0$ & $r \geq 4.0$ & & 2028 & 29.7 & 707 & 16.33669 & 21.13162 \\
\hline$r \leq 4.0$ & $r \geq 5.0$ & & 661 & 15.4 & 471 & 4.86385 & 14.26460 \\
\hline $\mathbf{r} \leq 5.0$ & $r \geq 6.0$ & & 022 & 3.8 & 466 & 0.0022 & 3.84146 \\
\hline$r \leq 6.0$ & $r \geq 7.0$ & & 2028 & 29. & 707 & 16.33669 & 21.13162 \\
\hline$r \leq 7.0$ & $r \geq 8.0$ & & 661 & 15.4 & 471 & 4.86385 & 14.26460 \\
\hline $\mathbf{r} \leq 8.0$ & $r=9.0$ & & 022 & 3.8 & 466 & 0.0022 & 3.84146 \\
\hline \multicolumn{8}{|c|}{ Russia Variables (INQ, HEALTH, EDU, FIN, INST, GDP, TO, C02, EC) $(P=2)$} \\
\hline$r=0.0$ & $r \geq 1.0$ & & $.2631^{*}$ & 117 & 082 & 84.79768* & 44.49720 \\
\hline
\end{tabular}




\begin{tabular}{|c|c|c|c|c|c|}
\hline $\mathrm{r} \leq 1.0$ & $\mathrm{r} \geq 2.0$ & $137.4654^{*}$ & 88.80380 & $49.46550^{*}$ & 38.33101 \\
\hline$r \leq 2.0$ & $r \geq 3.0$ & 87.99988* & 63.87610 & $45.30567^{*}$ & 32.11832 \\
\hline$r \leq 3.0$ & $r \geq 4.0$ & 42.69420 & 42.91525 & 20.74261 & 25.82321 \\
\hline$r \leq 4.0$ & $r \geq 5.0$ & 21.95160 & 25.87211 & 14.83326 & 19.38704 \\
\hline $\mathbf{r} \leq 5.0$ & $r \geq 6.0$ & 7.118341 & 12.51798 & 7.118341 & 12.51798 \\
\hline$r \leq 6.0$ & $r \geq 7.0$ & 42.69420 & 42.91525 & 20.74261 & 25.82321 \\
\hline$r \leq 7.0$ & $r \geq 8.0$ & 21.95160 & 25.87211 & 14.83326 & 19.38704 \\
\hline $\mathbf{r} \leq 8.0$ & $\mathrm{r}=9.0$ & 7.118341 & 12.51798 & 7.118341 & 12.51798 \\
\hline \multicolumn{6}{|c|}{ South Africa Variables (INQ, HEALTH, EDU, FIN, INST, GDP, TO, CO2, EC) $(P=2)$} \\
\hline$r=0.0$ & $r \geq 1.0$ & $144.4510^{*}$ & 91.34566 & 75.30734* & 48.07757 \\
\hline$r \leq 1.0$ & $r \geq 2.0$ & $122.4565^{*}$ & 61.87589 & $59.73667^{*}$ & 34.87687 \\
\hline$r \leq 2.0$ & $r \geq 3.0$ & $56.4571^{*}$ & 44.45413 & $40.32445^{*}$ & 24.58434 \\
\hline$r \leq 3.0$ & $r \geq 4.0$ & 34.5628 & 24.45507 & 19.34566 & 20.13162 \\
\hline$r \leq 4.0$ & $r \geq 5.0$ & 6.5461 & 11.45571 & 6.86543 & 17.26460 \\
\hline $\mathbf{r} \leq 5.0$ & $r \geq 6.0$ & 0.4526 & 6.56546 & 2.4522 & 6.84146 \\
\hline$r \leq 6.0$ & $r \geq 7.0$ & 34.5628 & 24.45507 & 19.34566 & 20.13162 \\
\hline$r \leq 7.0$ & $r \geq 8.0$ & 6.5461 & 11.45571 & 6.86543 & 17.26460 \\
\hline$r \leq 8.0$ & $r=9.0$ & 0.4526 & 6.56546 & 2.4522 & 6.84146 \\
\hline \multicolumn{6}{|c|}{ China Variables (INQ, HEALTH, EDU, FIN, INST, GDP, TO, C02, EC) $(P=2)$} \\
\hline$r=0.0$ & $r \geq 1.0$ & $143.2456^{*}$ & 127.45682 & $76.73578^{*}$ & 47.98350 \\
\hline$r \leq 1.0$ & $r \geq 2.0$ & $122.4453^{*}$ & 98.80789 & $44.46320^{*}$ & 35.35461 \\
\hline $\mathrm{r} \leq 2.0$ & $r \geq 3.0$ & $81.9994^{*}$ & 73.67610 & 40.38997* & 36.56772 \\
\hline $\mathrm{r} \leq 3.0$ & $r \geq 4.0$ & 43.69456 & 49.34525 & 23.43261 & 20.48721 \\
\hline$r \leq 4.0$ & $r \geq 5.0$ & 22.95450 & 29.55211 & 15.56326 & 12.36704 \\
\hline $\mathbf{r} \leq 5.0$ & $r \geq 6.0$ & 9.345441 & 10.44798 & 6.668341 & 5.56798 \\
\hline$r \leq 6.0$ & $r \geq 7.0$ & 43.69456 & 49.34525 & 23.43261 & 20.48721 \\
\hline$r \leq 7.0$ & $r \geq 8.0$ & 22.95450 & 29.55211 & 15.56326 & 12.36704 \\
\hline $\mathbf{r} \leq 8.0$ & $r=9.0$ & 9.345441 & 10.44798 & 6.668341 & 5.56798 \\
\hline \multicolumn{6}{|c|}{ India Variables (INQ, HEALTH, EDU, FIN, INST, GDP, TO, CO2, EC) $(P=2)$} \\
\hline$r=0.0$ & $r \geq 1.0$ & $230.45014^{*}$ & 121.4572 & 127.8795* & 54.34560 \\
\hline$r \leq 1.0$ & $r \geq 2.0$ & $193.8974 *$ & 84.34570 & 78.37895* & 38.54561 \\
\hline$r \leq 2.0$ & $r \geq 3.0$ & 142.6645 * & 61.85677 & 55.84343* & 29.14332 \\
\hline$r \leq 3.0$ & $r \geq 4.0$ & $86.5671^{*}$ & 47.93467 & 38.98754* & 21.84561 \\
\hline$r \leq 4.0$ & $r \geq 5.0$ & 29.57466 & 29.87243 & 19.23451 & 16.23704 \\
\hline$r \leq 5.0$ & $r \geq 6.0$ & 6.543152 & 11.33498 & 8.45715 & 9.45798 \\
\hline$r \leq 6.0$ & $r \geq 7.0$ & 86.56717 & 47.93467 & 38.98754 & 21.84561 \\
\hline$r \leq 7.0$ & $r \geq 8.0$ & 29.57466 & 29.87243 & 19.23451 & 16.23704 \\
\hline$r \leq 8.0$ & $r=9.0$ & 6.543152 & 11.33498 & 8.45715 & 9.45798 \\
\hline
\end{tabular}

Note: $r$ denotes no. of co-integrating vectors; and $\left(^{*}\right)$ denotes rejection @ 95\% critical value (CV).

\begin{tabular}{lllllll} 
Appendix 2D: Robustness check: POLS and GMM & \\
\hline Variables & $\begin{array}{l}\text { Dependent Variable: INQ } \\
\text { POLS } \\
\text { Coeff. }\end{array}$ & t-stats. & p-value & $\begin{array}{l}\text { GMM } \\
\text { Coeff. }\end{array}$ & t-stats. & p-value \\
\hline ln_GDP & 0.72539 & 13.62 & .0562535 & 0.56257 & 9.33 & .097649 \\
ln_INST & 0.12363 & 2.43 & $-.014223^{* *}$ & 0.56875 & 4.73 & $-.043256^{* *}$ \\
ln_C02 & 0.86353 & 10.97 & -.012552 & -12.453 & 1.56 & -.164746 \\
ln_FIN & 0.62452 & 11.43 & .153363 & 0.65743 & 2.67 & .1863635 \\
ln_HEALTH & 0.46252 & 15.33 & -.001636 & 0.76533 & 5.62 & -.012536 \\
ln_EDU & -0.6353 & -7.67 & $-.043525^{* *}$ & -0.17654 & -14.41 & $-.076363^{* *}$ \\
ln_TO & -0.1535 & 5.73 & .0065363 & -0.16543 & -6.67 & $.0156373^{* * *}$ \\
ln_EC & 0.85363 & 11.34 & .166333 & 0.77543 & 12.64 & .1673353 \\
ln_EXR & 0.43353 & 3.66 & - & 0.43554 & 5.34 & $-.003425^{* *}$ \\
& & & $.0013636^{* *}$ & & &
\end{tabular}




\begin{tabular}{|c|c|c|c|c|c|c|}
\hline \multicolumn{7}{|c|}{$\begin{array}{l}\text { Journal of Economics and Behavioral Studies (ISSN: 2220-6140) } \\
\text { Vol. 13, No. 3, pp. 1-23, June 2021 } \\
\end{array}$} \\
\hline ln_INF & -0.13852 & -5.54 & $.0012636^{* *}$ & -0.65749 & -7.36 & $-.0015262^{* *}$ \\
\hline Constant & 5.25257 & 6.73 & $0.00101^{*}$ & 4.43573 & 4.17 & $0.00102^{*}$ \\
\hline Obs. & 140 & & & 140 & & \\
\hline $\mathrm{R}^{2}$ & 0.7386 & & & 0.6833 & & \\
\hline Adj. $R^{2}$ & 0.7963 & & & 0.7154 & & \\
\hline F Statistics & $0.001^{* *}$ & & & & & \\
\hline $\operatorname{AR}(2)$ & ------- & & & 0.301 & & \\
\hline Hansen Test & ------ & & & 0.169 & & \\
\hline
\end{tabular}

Note: ${ }^{*}$ and ${ }^{* *}$ denotes statistical significance at $1 \%$ and $5 \%$ respectively.

Source: Authors Computation.

Appendix 2E: The Measure of Constructs (Dependent and Explanatory Variable)

\begin{tabular}{|c|c|c|c|}
\hline Variable & Measure & Author & Source of Data \\
\hline INQ & $\begin{array}{l}\text { Composite social inequality } \\
\text { index }\end{array}$ & Author's construction & $\begin{array}{l}\text { World Bank's World Development } \\
\text { Indicators; International } \\
\text { Monetary Fund, International } \\
\text { Financial Statistics and data files }\end{array}$ \\
\hline GDP & $\begin{array}{l}\text { Real level of GDP per capita } \\
\text { (constant } 2005 \text { US } \$ \text { ) (proxy } \\
\text { for economic growth) }\end{array}$ & 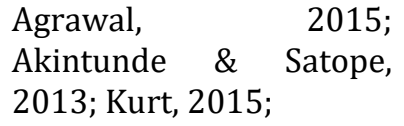 & $\begin{array}{l}\text { World Bank's World } \\
\text { Development } \\
\text { Indicator Database }\end{array}$ \\
\hline Health & $\begin{array}{l}\text { Total government } \\
\text { expenditure on Health }\end{array}$ & $\begin{array}{l}\text { Eggoh et al., } 2015 ; \\
\text { Adelowokan, } \\
\text { Strittmatter \& } 2012 ; \\
2011\end{array}$ & $\begin{array}{l}\text { World Bank's World } \\
\text { Development } \\
\text { Indicator Database }\end{array}$ \\
\hline EDU & $\begin{array}{l}\text { Weighted average of } \\
\text { government expenditure in } \\
\text { primary and secondary and } \\
\text { tertiary education }\end{array}$ & $\begin{array}{l}\text { Younsi \& Bechtini, 2018; } \\
\text { Jamel \& Maktouf, } 2017\end{array}$ & $\begin{array}{l}\text { World Bank's World Development } \\
\text { Indicators }\end{array}$ \\
\hline FIN & $\begin{array}{l}\text { composite financial sector } \\
\text { development } \\
\text { index }\end{array}$ & $\begin{array}{l}\text { Younsi \& Bechtini, 2018; } \\
\text { Maryam et al., } 2017\end{array}$ & $\begin{array}{l}\text { International Monetary Fund, } \\
\text { International Financial Statistics } \\
\text { and data files; World Bank's } \\
\text { World Development Indicators }\end{array}$ \\
\hline INSTFIT & $\begin{array}{l}\text { Aggregations of economic, } \\
\text { political and institutional } \\
\text { indexes (proxy for } \\
\text { institutional fitness) }\end{array}$ & $\begin{array}{l}\text { Eggoh, Houeninvo \& } \\
\text { Sossou, } \\
\text { Adelowokan, 2015; } \\
\text { David., Bloom, \& Canning, } \\
\text { 2008; Strittmatter \& } \\
\text { Sunde, 2011; Licumba., } \\
\text { Dzator \& Zhang, } 2016\end{array}$ & $\begin{array}{l}\text { World Bank Databases (World } \\
\text { Governance Index-WGI- ). }\end{array}$ \\
\hline TO & Total Trade (\% of GDP) & $\begin{array}{l}\text { Jamel \& Maktouf, 2017; } \\
\text { Eggoh et al., } 2015\end{array}$ & $\begin{array}{l}\text { World Bank's World Development } \\
\text { Indicators; OECD } \\
\text { National Accounts data files }\end{array}$ \\
\hline $\mathrm{CO}_{2}$ & $\begin{array}{l}\mathrm{CO} 2 \text { emissions (metric tons } \\
\text { per capita) }\end{array}$ & $\begin{array}{l}\text { Jamel \& Maktouf, 2017; } \\
\text { Maryam et al., 2017; } \\
\text { Eggoh et al., } 2015\end{array}$ & $\begin{array}{l}\text { World Bank's World Development } \\
\text { Indicators }\end{array}$ \\
\hline EN & $\begin{array}{l}\text { Energy consumption (in } \\
\text { kilotons) }\end{array}$ & $\begin{array}{l}\text { Jamel \& Maktouf, 2017; } \\
\text { Maryam et al., 2017; } \\
\text { Eggoh et al., } 2015\end{array}$ & $\begin{array}{l}\text { World Bank's World Development } \\
\text { Indicators }\end{array}$ \\
\hline
\end{tabular}

